\title{
New observations on high-pressure phases in a shock melt vein in the Villalbeto de la Peña meteorite: Insights into the shock behavior of diopside
}

\section{Marina MARTINEZ ${ }^{1 *}$, Adrian J. BREARLEY ${ }^{1}$, Josep M. TRIGO-RODRIGUEZ ${ }^{2}$, Jordi LLORCA ${ }^{3}$.}

${ }^{1}$ Department of Earth \& Planetary Sciences, MSC03-2040, 1University of New Mexico, Albuquerque, NM 87131, USA (mmartinezjimenez@unm.edu)

${ }^{2}$ Institute of Space Sciences (CSIC-IEEC), Campus UAB, Carrer de Can Magrans, s/n, 08193 Bellaterra (Barcelona), Catalonia.

${ }^{3}$ Institut de Tècniques Energètiques i Centre de Recerca en Nanoenginyeria, Universitat Politècnica de Catalunya, Diagonal 647, ETSEIB, 08028 Barcelona, Catalonia.

${ }^{*}$ Corresponding author.

\begin{abstract}
The petrology and mineralogy of shock melt veins in the L6 ordinary chondrite host of Villalbeto de la Peña, a highly shocked, L chondrite polymict breccia, have been investigated in detail using Scanning Electron Microscopy, Transmission Electron Microscopy, Raman Spectroscopy, and Electron Probe Microanalysis. Entrained olivine, enstatite, diopside, and plagioclase are transformed into ringwoodite, low-Ca majorite, high-Ca majorite, and an assemblage of jadeite-lingunite, respectively, in several shock melt veins and pockets. We have focused on the shock behavior of diopside in a particularly large shock melt vein (10 $\mathrm{mm}$ long and up to $4 \mathrm{~mm}$ wide) in order to provide additional insights into its high-pressure polymorphic phase transformation mechanisms. We report the first evidence of diopside undergoing shock-induced melting, and the occurrence of natural Ca-majorite formed by solid-state transformation from diopside. Magnesiowüstite has also been found as veins injected into diopside in the form of
\end{abstract}


nanocrystalline grains that crystallized from a melt and also occurs interstitially between majorite-pyrope grains in the melt-vein matrix. In addition, we have observed compositional zoning in majorite-pyrope grains in the matrix of the shock-melt vein, which has not been described previously in any shocked meteorite. Collectively, all these different lines of evidence are suggestive of a major shock event with high cooling rates. The minimum peak-shock conditions are difficult to constrain, because of the uncertainties in applying experimentally-determined high-pressure phase equilibria to complex natural systems. However, our results suggest that conditions between 16 to $28 \mathrm{GPa}$ and 2000-2200 ${ }^{\circ} \mathrm{C}$ were reached.

\section{Introduction}

Many ordinary chondrites record hypervelocity impacts in asteroidal settings that triggered the occurrence of high-pressure phase transformations (Chen et al. 1996; Sharp et al. 1997; Tomioka and Kimura 2003; Ohtani et al. 2004; Sharp and DeCarli 2006; Xie et al. 2006; Zhang et al. 2006; Miyahara et al. 2008, 2011; Ozawa et al. 2009; Feng et al. 2011). During these dynamic events, the major mineralogical constituents of ordinary chondrites, olivine, pyroxene, and plagioclase, undergo a variety of phase transformations that provide insights into high-pressure polymorphic phase transformations, as well as the conditions of shock melt vein formation during asteroidal impacts. These samples provide a unique opportunity to study natural high-pressure phases that are stable in the mantle of the Earth, but are inaccessible for study. For example, several important, natural high-pressure phases have been discovered in meteorites, such as bridgmanite (Tomioka and Fujino 1997; Tschauner et al. 2014), tissintite (Ma et al. 2015), and tetragonal majorite (Tomioka and Fujino 1997; Xie and Sharp, 2007; Tomioka et al. 2016).

The high-pressure polymorphs of olivine - wadsleyite $\left(\beta-(\mathrm{Fe}, \mathrm{Mg}) \mathrm{Si}_{2} \mathrm{O}_{4}\right)$ and ringwoodite $\left(\gamma-(\mathrm{Fe}, \mathrm{Mg}) \mathrm{Si}_{2} \mathrm{O}_{4}\right)-$, pyroxene - majorite $\left(\mathrm{MgSiO}_{3}\right.$-garnet $)+\mathrm{CaSiO}_{3}-$ perovskite, akimotoite $\left(\mathrm{MgSiO}_{3}\right.$-ilmenite $)+\mathrm{CaSiO}_{3}$-perovskite, tetragonal majorite + $\mathrm{CaSiO}_{3}$-perovskite, and bridgmanite $\left(\mathrm{MgSiO}_{3}\right.$-perovskite $)+\mathrm{CaSiO}_{3}$-perovskite -, and plagioclase - jadeite $\left(\mathrm{NaAlSi}_{2} \mathrm{O}_{6}\right)$ or tissintite $\left(\mathrm{CaAlSi}_{2} \mathrm{O}_{6}\right)+$ silica phase, lingunite ( $\mathrm{NaAlSi}_{3} \mathrm{O}_{8}$-hollandite), and $\mathrm{NaAlSiO}_{4}$ (calcium ferrite-type), have been extensively 
studied in shocked meteorites and in high-pressure experimental studies. Hydrostatic, multi-anvil experiments are most commonly used to understand the high-pressure phase equilibria of these polymorphs and their melting relationships (e.g., Agee et al. 1995; Chen et al. 1996; Ohtani et al. 2004; Xie et al. 2006; Akaogi et al. 2004, 2010). Asteroidal impacts, however, generate natural conditions of high-pressures that last from tens of milliseconds to a few seconds (Sharp and DeCarli 2006; Gillet et al. 2007), resulting in conditions which may deviate substantially from equilibrium. Therefore, although hydrostatic multianvil press experiments can simulate high-pressure and temperature conditions on the scale of one to several seconds (e.g., Akaogi et al. 2004), for extremely fast shock events, such as those that occur in nature, some uncertainties still exist.

Even though diopside is found widely in ordinary chondrites (Brearley and Jones 1998), its abundance is comparatively low and very few occurrences of its high-pressure polymorph Ca-rich majorite have been reported in the literature. Calcium-rich majorite was first reported in the Shergotty Martian meteorite (Malavergne et al. 2001). It has an augitic composition $\left(\mathrm{En}_{46} \mathrm{Fs}_{29} \mathrm{Wo}_{25}\right)$ and formed by solid-state transformation. Subsequently, Carich majorite has been found in just two ordinary chondrites: Yamato 75100 (H6) (Tomioka and Kimura 2003), and Tenham (L6) (Xie and Sharp 2007). In Yamato 75100, the Ca-rich majorite is formed by a dissociation reaction of diopside by a solid-state mechanism. Tomioka and Kimura (2003) found that the majorite has a different composition from the precursor diopside and hence, they suggested that formation by crystallization from a melt, rather than by solid-state transformation, should also be considered. However, they ruled out this possibility, because the majorite has low $\mathrm{Al}$ and $\mathrm{Fe}$ contents, despite being in contact with melted plagioclase. The Ca-rich majorite $\left(\mathrm{En}_{65} \mathrm{Fs}_{9} \mathrm{Wo}_{26}\right)$ in Yamato 75100 has a granular texture and is associated with a Ca-rich glass $\left(\mathrm{En}_{23} \mathrm{Fs}_{5} \mathrm{Wo}_{72}\right)$, whereas in Tenham, Ca-rich majorite $\left(\mathrm{En}_{64} \mathrm{Fs}_{10} \mathrm{Wo}_{27}\right)$ occurs as a nanometer symplectic intergrowth with amorphous Ca-poor glass (Xie and Sharp 2007). Electron diffraction data for the Carich majorite are consistent with tetragonal rather than cubic symmetry, but with larger unit cell parameters than Mg-rich majorite, which Xie and Sharp (2007) attributed to the expansion of the unit cell due to the high $\mathrm{Ca}$-content. 
Chopelas and Serghiou (2002) found that the room temperature Raman spectrum of diopside at $20.2 \mathrm{GPa}$ was nearly identical to that at $1 \mathrm{~atm}$, demonstrating that the transformation of diopside into Ca-rich majorite is strongly temperature dependent, consistent with diopside phase transitions reported by Akaogi et al. (2004). For the Yamato 751000 H6 ordinary chondrite, Tomioka and Kimura (2003) estimated a solidus P-T for the shock melt vein of $18-24 \mathrm{GPa}$ at $1100-1900^{\circ} \mathrm{C}$. In the Sixiangkou L5 ordinary chondrite, diopside in the melt vein did not undergo a phase transformation, but coexists with ringwoodite. This association constrains the stability field of diopside under high P-T conditions and suggests that either the local P-T conditions did not exceed the stability field of diopside, or the rate of phase transformation of diopside is very low and the shock duration was too short to induce the transformation (Zhang et al. 2006). The current available constraints indicate a shock pressure of $20 \mathrm{GPa}$, low temperatures (less than $\sim 1500{ }^{\circ} \mathrm{C}$ ), and a peak shock duration of less than several seconds (previously suggested by Chen et al. 2002, 2004, 2006) in order to prevent transformation into Ca-majorite. However, Zhang et al. (2006) also suggested that the preservation of diopside during large shock events of several seconds to minutes of duration implies that the transformation rates of diopside have to be very sluggish. These observations demonstrate that there is still significant uncertainty in the high P-T transformation behavior of diopside in shocked ordinary chondrites.

In the present work, we have studied in detail the transformation behavior of diopside as a result of high-pressure shock metamorphism in the L6 host rock of the Villalbeto de la Peña L6 ordinary chondrite polymict breccia (hereafter, Villalbeto), a meteorite that fell in Spain in 2004 (Llorca et al. 2005, Bischoff et al. 2013). This paper focuses on an unusually large shock melt vein with entrained host rock fragments. The aims of this study are to (i) investigate in detail the mineralogy and petrology of the larger shock melt vein, (ii) more fully understand the high-pressure transformation behavior of diopside in the shock vein, and (iii) constrain the peak shock conditions experienced by Villalbeto.

\section{Methods}


A rectangular polished thin section of Villalbeto, $37 \mathrm{~mm}$ wide and $18 \mathrm{~mm}$ long on its maximum dimensions, which is in the possession of the Meteorite Collection at the Institute of Space Sciences (ICE-CSIC) in Barcelona (Catalonia), was used in this study. The textural, mineralogical, and petrological characteristics of Villalbeto were characterized using a variety of different analytical techniques described below.

Petrographic characterization of the sample was performed on the polished thin section by optical microscopy using transmitted and reflected light. A mosaic of the thin section was acquired using a ZEISS Scope petrographic microscope in order to locate the targeted regions correctly and also to provide the petrologic context of regions of interest within the sample. For scanning electron microscopy (SEM), we used a FEI Quanta 650 field emission gun SEM with a backscattered electron detector (BSED) at the Institut Català de Nanociència i Nanotecnologia (ICN2). X-ray spectra and X-ray maps were acquired on a FEI Quanta 3D FEG-SEM/FIB using an EDAX Genesis EDS system equipped with an Apollo 40 SDD $40 \mathrm{~mm}^{2}$ EDS detector at the University of New Mexico. The thin section was carbon coated prior to SEM imaging and X-ray mapping and was analyzed under high-vacuum conditions. Semiquantitative EDS analyses obtained on the FEI Quanta 650 at ICN2 were used for mineral identification. The standards used for EDS analyses were as follows: calcite $\left(\mathrm{CaCO}_{3}\right)$ for $\mathrm{C}$; silica $\left(\mathrm{SiO}_{2}\right)$ for $\mathrm{O}$ and $\mathrm{Si}$; albite $\left(\mathrm{NaAlSi}_{3} \mathrm{O}_{8}\right)$ for $\mathrm{Na} ; \mathrm{MgO}$ for $\mathrm{Mg} ; \mathrm{Al}_{2} \mathrm{O}_{3}$ for $\mathrm{Al} ; \mathrm{FeS}_{2}$ for $\mathrm{S}$; wollastonite $\left(\mathrm{CaSiO}_{3}\right)$ for $\mathrm{Ca}$; $\mathrm{Mn}$ metal for $\mathrm{Mn}$; and $\mathrm{Fe}$ metal for $\mathrm{Fe}$.

A total of four FIB sections were prepared from different Ca-rich high-pressure phases using a FEI Quanta 3D Dualbeam® FEG-SEM/FIB instrument in the Department of Earth and Planetary Sciences, University of New Mexico. Platinum strips, $\sim 2 \mu \mathrm{m}$-wide, $\sim 2.5 \mu \mathrm{m}$-thick, and up to $20 \mu \mathrm{m}$ in length, were first deposited across each area of interest to protect the TEM sections from ion beam damage during sample preparation. The sections were extracted from the thin section by the in-situ lift-out technique using an Omniprobe 200 micromanipulator and were attached to copper $(\mathrm{Cu})$ Omniprobe TEM half grids. Ion milling to electron transparency was carried out at an accelerating voltage of $30 \mathrm{kV}$ and a beam current gradually decreasing from $0.5 \mathrm{nA}$ to $50 \mathrm{pA}$. 
Detailed characterization of the microstructures and mineralogy of the FIB sections were conducted using a JEOL 2010F FASTEM FEG scanning transmission electron microscope (STEM), operated at $200 \mathrm{kV}$. The FIB sections were studied using highresolution TEM (HR-TEM), high-angle annular dark-field (HAADF) scanning TEM (STEM), and selected-area electron diffraction. Digital TEM images were acquired and processed using GATAN Microscopy Suite® (GMS) imaging software. In addition, full spectral X-ray maps were collected in STEM mode using the JEOL 2010F, and quantitative X-ray microanalyses were obtained using an Oxford AZTec X-ray analysis system with a X-Max $80 \mathrm{~N} 80 \mathrm{~mm}^{2}$ SDD energy dispersive X-ray spectrometer (EDS) detector system. Quantification of EDS spectra was carried out using the Cliff-Lorimer thin film approximation using theoretical $\mathrm{k}$-factors.

Raman spectroscopy provides information about the chemical bonds in solids and, therefore, allows the identification of high-pressure polymorphs (Sharp and deCarli, 2006; Fritz and Greshake, 2009, and references therein). Raman spectra were recorded in backscattering geometry at room temperature, using the $514.5 \mathrm{~nm}$ line of an argon-ion laser with a Jobin-Yvon T-64000 Raman spectrometer attached to an Olympus microscope, and equipped with a liquid nitrogen-cooled CCD detector at ICMAB (Barcelona). The instrument has high-lateral spatial resolution of about $\sim 1 \mu \mathrm{m}$. To avoid degradation due to heating, the laser power on the sample was kept between 0.6-0.7 $\mathrm{mW}$. The Raman spectrometer provided high-resolution spectra in working windows between 100 and 1400 $\mathrm{cm}^{-1}$. The identification of mineral compounds was performed using the database from the Handbook of Minerals Raman Spectra (ENS-Lyon, France) and from The RRUFF Project (Lafuente et al. 2015).

Chemical compositions of minerals were determined using a JEOL JXA-8230 electron microprobe at the Scientific and Technological Center of the University of Barcelona. Quantitative wavelength dispersive X-ray spectrometry (WDS) analyses were conducted using a $20 \mathrm{kV}$ accelerating voltage and $15 \mathrm{nA}$ beam current with a focused electron beam of $1 \mu \mathrm{m}$ diameter for all phases except for plagioclase, where a 3 to $5 \mu \mathrm{m}$ beam was used to minimize alkali loss. Wollastonite $\left(\mathrm{SiO}_{2}, \mathrm{CaO}\right)$, corundum $\left(\mathrm{Al}_{2} \mathrm{O}_{3}\right)$, rutile $\left(\mathrm{TiO}_{2}\right), \mathrm{Cr}_{2} \mathrm{O}_{3}\left(\mathrm{Cr}_{2} \mathrm{O}_{3}\right)$, albite $\left(\mathrm{Na}_{2} \mathrm{O}\right)$, periclase $(\mathrm{MgO})$, rhodonite $(\mathrm{MnO}), \mathrm{Fe}_{2} \mathrm{O}_{3}(\mathrm{FeO})$, Co 
$(\mathrm{CoO})$, $\mathrm{Ni}(\mathrm{NiO})$, orthoclase $\left(\mathrm{K}_{2} \mathrm{O}\right), \mathrm{FeS}_{2}(\mathrm{~S})$, and apatite $\left(\mathrm{P}_{2} \mathrm{O}_{5}\right)$ were used as standards. Full ZAF corrections were applied to the data to obtained quantitative analyses.

\section{Results}

\subsection{Petrographic description}

Villalbeto is currently classified as a polymict chondritic breccia (Bischoff et al. 2013). The sample of the host rock analyzed in this work is a L6 ordinary chondrite with shock stage S4 (Llorca et al. 2005). The major constituents of Villalbeto in the host rock are olivine ( $\left.\mathrm{Fo}_{75}\right)$, enstatite $\left(\mathrm{En}_{77} \mathrm{Fs}_{22} \mathrm{Wo}_{1}\right)$, diopside $\left(\mathrm{En}_{47} \mathrm{Fs}_{8} \mathrm{~W}_{45}\right)$, plagioclase completely transformed to maskelynite $\left(\mathrm{Ab}_{79} \mathrm{An}_{15} \mathrm{Or}_{6}\right)$, metallic iron-nickel, and troilite. Representative mineral analyses are reported in Table 1. Minor phases include chromite and phosphates such as shocked chlorapatite and merrillite. Hence, our results are in agreement with Llorca et al. (2005) for olivine, low-Ca pyroxene, and maskelynite (Table 1). Llorca et al. (2007) assumed that plagioclase was present in the host rock and explained the lack of its Raman bands in their results by the effect of strong fluorescence at $400-520 \mathrm{~cm}^{-1}$ that possibly obscured the most intense feldspar Raman bands at about $500 \mathrm{~cm}^{-1}$. However, in this study, we did not find any crystalline plagioclase in Villalbeto; all the plagioclase in the host rock has been transformed into maskelynite based on petrographic microscopy observations and Raman spectroscopy analyses. Based on the presence of large (up to $10 \mathrm{~mm}$-size) shock melt veins and pockets with abundant ringwoodite, majorite, and lingunite, and complete transformation of plagioclase to maskelynite in the host rock, we suggest that Villalbeto de la Peña should be reclassified as shock stage S6 instead of S4.

In the studied thin section, most chondrules in the host rock are poorly defined, but some chondrules with barred olivine and porphyritic textures can still be distinguished. Hence, the overall sample has a highly recrystallized texture characteristic of a type 6 chondrite (Llorca et al. 2005). There are two large shock veins and several minor veins and melt pockets within the thin section. The main vein has an elongated triangular shape (10 $\mathrm{mm}$ long $\mathrm{x} 4 \mathrm{~mm}$ wide), it is located at one side of the thin section, and crosscuts the meteorite (Fig. 1a). This vein contains several high-pressure phases that are the result of 
transformation of entrained clasts such as Ca-poor majorite, Ca-rich majorite, jadeitelingunite, and ringwoodite (Fig. 1b). On the opposite side of the thin section, there is a complex network of veins with different widths that meanders throughout a large area of the host rock and is associated with several minor shock melt pockets. An example of a thin vein, $\sim 5 \mu \mathrm{m}$ size in width, from this network of shock veins is shown in Figure $2 \mathrm{a}$, and consists predominantly of glass with metal-sulfide droplets, associated with rapid quench. At the contact with the shock melt veins and pockets, the host rock shows a pronounced brown staining (Fig. 1b), inferred to correspond to recrystallization (Stöffler et al. 1991). Olivine and pyroxene grains contain pervasive mosaicism and some pyroxenes have a homogeneous distribution of small sulfide inclusions $(\sim 1-3 \mu \mathrm{m})$. Maskelynite in the host rock is abundant and consistently has a smooth texture without fractures. However, many of maskelynite grains contain small inclusions ( 1-5 $\mu \mathrm{m}$-size) of metal-troilite, or euhedral Cr-spinel with troilite. The Cr-spinel grains often show a distinct crystallographic orientation suggesting they may have exsolved from the precursor plagioclase prior to shock transformation to maskelynite. The texture is similar to that described in a plagioclase-chromite inclusion from the Los Martinez L6 chondrite (Brearley et al. 1991). In contrast, plagioclase in a foreign dark clast in Villalbeto studied by Bischoff et al. (2013) contains inclusions of metal, troilite, and Cr-spinel that are heterogeneously dispersed and randomly oriented.

The large shock vein that we have studied has a pronounced flow texture defined by the alignment of elongated clasts consisting of high-pressure minerals entrained within the shock vein and of metal-troilite blebs in its matrix, which occur in bands (Figs. 1 and 2b). The shock vein consists of two distinct types of domains with distinct textural and mineralogical characteristics that are intermingled parageneses. The first type mostly consists of abundant, large $(\sim 50-600 \mu \mathrm{m})$, rounded, fractured, and unfractured host rock fragments entrained in the melt vein, crosscut by several fractures (Fig. 1b). The second type is a fine-grained melt matrix of idiomorphic majorite-pyrope crystals with blebs that consist of an intergrowth of FeNi and troilite that formed by rapid quenching of a FeNi-FeS melt, with interstitial magnesiowüstite in the wider regions (Fig. 2c). The two types of domains are distributed randomly within the vein along its length. Large chromite grains $(\sim 120 \mu \mathrm{m}$ in size) with exsolution textures are also present within the vein (Fig. $2 \mathrm{~d}$ ). 


\section{Table 1.}

\section{Fig. 1.}

Electron microprobe analyses and Raman spectra show that original low-Ca pyroxene, high-Ca pyroxene, olivine, and plagioclase in the shock vein are transformed into their high-pressure polymorphs, low-Ca majorite, high-Ca majorite, ringwoodite, and a mixture of jadeite-lingunite, respectively (Table 1, Fig. 3). The high-pressure shock transformation products of plagioclase in the host rock, maskelynite, show slightly variable $\mathrm{CaO}, \mathrm{Na}_{2} \mathrm{O}$, and $\mathrm{FeO}$ contents compared to its high-pressure polymorph, lingunite in the vein, which contains no detectable FeO measured by EPMA.

We also observe a unique texture consisting of veins of troilite that define a complex network in the pyroxene (Fig. 2d,e) and is probably the result of shock injection of molten troilite into the pyroxene. Although veins usually have random orientations through the pyroxene, in some regions they follow the pyroxene cleavage. This texture is observed at the wider region of the largest vein and can occur within large radial fractures in chondrules ( 0.7-1 mm in size) that are entrained within the vein (Fig. 2e). A smaller vein contains a diverse range of shock effects that were not investigated in detail in this study. These include high-pressure phases such as Ca-rich majorite grains, blue ringwoodite, tuite, and chromite-maskelynite assemblages (e.g., Fig. 3, bottom left). Complex shock textures are also common including dissociation textures in $\mathrm{Mg}_{2} \mathrm{SiO}_{4}$ clasts showing radial symplectites of a high $\mathrm{Z}$ phase and a low $\mathrm{Z}$ phase (Fig. 2f), many Fe-rich veins crosscutting

entrained high-pressure clasts in chondrules, $\mathrm{Mg}$-rich rims on the edge of entrained olivine chondrules (e.g., Fig. 2f), and metal-troilite bleb accumulations at the chondrule margins.

Fig 2.

Fig. 3.

\subsection{Diopside to tetragonal Ca-rich majorite}

Calcium-rich majorite grains are produced by high-pressure transformation of Carich pyroxene. An unusual anisotropic $\mathrm{Ca}$-rich silicate phase with a composition consistent with diopside (En ${ }_{47} \mathrm{Fs}_{8} \mathrm{Wo}_{45}$ ) (Table 1), based on EPMA was identified in the shock vein, associated with ringwoodite. This phase was identified as Ca-rich majorite based on Raman 
Spectroscopy (Fig. 3). The optical anisotropy of these grains, seen by cross-polarized light optical microscopy, suggested that these grains might have tetragonal symmetry $\left(I 4_{1} / a\right)$,

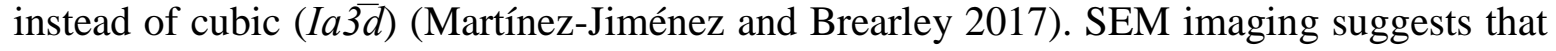
the Ca-rich majorite has a very fine-scale, granular microstructure at the submicron scale, which is too fine-grained to resolve. Therefore, we investigated its structure and chemistry in detail using TEM. Two FIB sections (designated FIB1 and FIB2) were extracted from this Ca-rich majorite grain (Fig. 4a).

Transmission electron microscopy shows that it has a complex structure consisting of single crystals of Ca-rich majorite (a few microns in size) embedded within a nanometerscale symplectic intergrowth of Ca-rich majorite and glass, in which the finger-like crystals and glass have the same sizes ( $20 \mathrm{~nm}$ width, and up to $1 \mu \mathrm{m}$ long) (Figs. 4b-d and 5b,c). The single crystal shows the same symplectic dissociation gradationally occurring at its margins (Fig. 4b). Scanning transmission electron microscope X-ray mapping shows that the Ca-rich majorite in the symplectic intergrowth is Mg-rich and Ca-poor compared with single-crystal Ca-rich majorite and the glass shows the inverse relationship, being Ca-rich. A [111] zone axis SAED pattern (Fig. 4e) obtained from the single-crystal Ca-rich majorite in FIB1 shows reflections of the type $\{h 0 l\}$ (where $h, 1=$ odd) and therefore, violates the extinction rule for Bragg diffraction for cubic space group $I \bar{a} \bar{d} d$. This observation might imply that the garnet has tetragonal symmetry instead of cubic, the most common symmetry found in majorites from meteorites (e.g., Coleman 1977; Tomioka and Kimura 2003; Chen and Xie 2008). Furthermore, the [211] zone axis in Fig. 5d shows the diffraction maxima $\{0 k l\}$ where $(k, l=$ odd), which is also indicative of tetragonal symmetry. The faint reflections $\{0 k l\}$ where $(k, l=$ odd) are forbidden reflections in the cubic structure, but appear in the tetragonal space group $I 4_{1} / a$ due to increased ordering. However, neither of these orientations can be used to identify the symmetry of the garnet definitively as tetragonal. In each of these diffraction patterns, the additional forbidden reflections may simply be due to multiple diffraction effects because the sample is insufficiently thin. Unfortunately, due to limited tilt on the TEM instrument used for the electron diffraction analysis, it was not possible to tilt the crystal to either the [100] or [010] zone axes, which would uniquely define the Ca-majorite as cubic or tetragonal. Based on 
the data we have, we cannot resolve the symmetry of the Ca-majorite, although optical anisotropy may suggest, however, it is tetragonal (Fig. 1c).

The diffraction pattern from the symplectic intergrowth shows a diffuse diffraction ring, which is consistent with the presence of glass (Fig. 4f). The presence of glass is also consistent with the Raman spectrum, which shows broader peaks associated with amorphous material in comparison with Ca-poor majorite spectra, which have pronounced and narrower peaks (Fig. 3). In the FIB2 TEM section, shown in Figure 5, Ca-rich majorite crystals represent the major part of the section in comparison to the symplectic intergrowth. Ca-rich majorite forms a mosaic of subgrains $(\sim 2 \mu \mathrm{m})$, with some amorphous material between the crystallites (Fig. 5a). The symplectic intergrowth consists of Ca-poor majorite fingers within Ca-rich glass similar to the FIB1 TEM section. The electron diffraction data also show that the Ca-rich majorite crystals in the symplectic intergrowth all have the same crystallographic orientation, albeit with some misorientation, which is apparent in the arcs observed for individual diffraction maxima. Despite this misorientation, it is apparent that the symplectite crystallites have essentially the same orientation as the single crystal of Carich majorite that they surround.

\section{Fig. 4.}

\section{Fig. 5.}

\subsection{Diopside undergoing direct melting}

A third FIB section was extracted within an entrained chondrule fragment located in a wider region of the shock vein (Fig. 6). The chondrule fragment is $200 \mu \mathrm{m}$ wide and 500 $\mu \mathrm{m}$ long, and it is surrounded by melted matrix with abundant metal-troilite blebs and other rounded clasts of ringwoodite, shocked chromite, and shocked chlorapatite. This area within the chondrule fragment displays a complex relationship between the different phases shown in an X-ray map ( $\mathrm{Si}-\mathrm{Al}-\mathrm{Ca}$ ) in Figure 6a. The Ca-rich silicate grain has an irregular shape, contains several fractures, and is embedded in a more homogeneous-looking, isotropic phase with the same apparent composition observed by BSE imaging. It is associated with a jadeite-lingunite assemblage phase, which was identified by Raman spectroscopy (dark gray area in Fig. 6b). The FIB section was removed precisely from the 
fractured Ca-rich silicate phase across the interface with the surrounding, smooth homogeneous phase. Electron diffraction patterns of this phase show it is amorphous, whereas diffraction patterns from the fractured phase show that it is crystalline diopside, rather than the high-pressure polymorph, majorite. In the TEM, the interface between these two phases is extremely sharp and well-defined, and quantitative STEM-EDS data from the crystalline and amorphous phase show that they have identical compositions $\left(\mathrm{En}_{54} \mathrm{Fs}_{5} \mathrm{Wo}_{41}\right)$. Thus, we interpret the amorphous $\mathrm{Ca}$-rich phase with a $(\mathrm{CaMg}) \mathrm{Si}_{2} \mathrm{O}_{6}$ composition to be glass resulting from high-pressure melting of diopside. Scanning-TEM and dark-field STEM images also reveal a network of veins along fractures that are crystallographically oriented. Compositionally, the veins contain material with high concentrations of $\mathrm{FeO}(\sim 79 \mathrm{wt} \%)$ with minor $\mathrm{MgO}(\sim 8 \mathrm{wt} \%)$ (Fig. 6c). These veins have been identified as nanocrystalline magnesiowüstite based on their diffraction patterns, being ring patterns due to their small grain sizes (Fig. 6d). The EDS analyses from these veins also contain $\mathrm{SiO}_{2}$ and $\mathrm{CaO}$ suggesting that minor diopside or diopside melt probably occurs interstitially to the magnesiowüstite. Magnesiowüstite veins (0.1-0.4 $\mu \mathrm{m}$ width) are crystallographically oriented and are along the diopside (110) cleavage planes, as well as parallel to the (001) and (111) planes. They show many fractures that generally lie both parallel to and normal to the vein boundaries. The veins truncate at the edge of the diopside crystal, but arrays of pores (40 to $400 \mathrm{~nm}$ in size) extend into the glass from the truncation of the magnesiowüstite veins (Fig. 6c). In addition to the magnesiowüstite veins, pockets of a Ca-rich nanocrystalline phase also occur within the diopside and along the interfaces between the magnesiowüstite and the diopside. This Ca-rich phase has a higher FeO content than the diopside (Fig. 6c).

\section{Fig. 6.}

\subsection{Olivine to ringwoodite}

Based on Raman spectroscopy and EPMA, most olivine grains entrained in the shock melt are transformed to ringwoodite $\left(\mathrm{Mg}_{1.49} \mathrm{Fe}_{0.52} \mathrm{Si}_{0.99} \mathrm{O}_{4}\right.$, Table 1). No wadsleyite has been found. Ringwoodite grains are observed with different textures, with smooth monomineralic grains predominating (e.g., Fig. 4a). Polycrystalline ringwoodite aggregates are also found (Fig. 7a), similar to those seen in the Tenham (Xie and Sharp 2007; 
Langenhorst et al. 1995; Chen et al. 1996), Yamato 791384 (Miyahara et al. 2010), and Sixiangkou (Chen et al. 1996; 2007) chondrites. However, we have also identified oriented lamellae of ringwoodite in olivine grains in the host rock adjacent to the vein (Fig. 7b,c). Backscattered electron images show that lamellae are richer in $\mathrm{Fe}_{2} \mathrm{SiO}_{4}$ than the

surrounding host olivine. The respective widths and lengths of lamellae are $\sim 5 \mu \mathrm{m} x \sim 60$ $\mu \mathrm{m}$ in Fig. 7b, and less than $\sim 1 \mu \mathrm{m} x \sim 10 \mu \mathrm{m}$ in Fig. 7c. Ringwoodite with a slightly blue coloration in plane polarized transmitted light was also recognized in another melt pocket associated with the second shock vein.

Fig. 7.

\subsection{Jadeite-lingunite}

The jadeite-lingunite phase, which was identified by Raman spectrometry, EPMA, and TEM, formed subsequent to the breakdown of feldspar, being the high-pressure polymorph of plagioclase. It is a predominant phase in the Villalbeto shock melt veins, commonly occurring within chondrule fragments, interstitial to ringwoodite and majorite. The jadeite-lingunite grains are anhedral in shape with grain sizes of $0.5-1 \mu \mathrm{m}$. They are optically isotropic, but some grains show slight anisotropy that may indicate incomplete transformation to the high-pressure phase. Electron microprobe analyses of the jadeitelingunite phase show a chemical composition of $\mathrm{Na}_{0.63} \mathrm{Ca}_{0.12} \mathrm{~K}_{0.03} \mathrm{Mg}_{0.01} \mathrm{Fe}_{0.01} \mathrm{Al}_{1.18} \mathrm{Si}_{2.87} \mathrm{O}_{8}$ (Table 1). We attribute some analytical errors due to the focused electron beam $(1 \mu \mathrm{m})$ used for the analysis, which likely caused volatile loss in the host rock maskelynite and thereby, can cause compositional differences (Ribbe and Smith 1966; Spray and Rae 1995). Thus, higher $\mathrm{Na}$ contents in the jadeite-lingunite phase may be related to less volatile loss compared to maskelynite. However, although the composition is close to its parental phase in the host rock, lingunite shows a significant enrichment in $\mathrm{MnO}(0.22 \mathrm{wt} \%)$ that is not apparent in the host rock maskelynite (0.02 wt\%) (Table 1), which may suggest incorporation during melting. The Raman spectra of the jadeite-lingunite phase vary slightly among measurements, with typical peaks at 214, 278, 383, 595, 640, 700, 770, 825, 930, 1113, and $1189 \mathrm{~cm}^{-1}$ (Fig. 2). Some of the peaks correspond to jadeite (383 and 700 $\mathrm{cm}^{-1}$ peaks), and others to lingunite $\left(214,278,640,770\right.$, and $\left.825 \mathrm{~cm}^{-1}\right)$. Majorite Raman 
peaks are also identified (593 and $931 \mathrm{~cm}^{-1}$ peaks), probably because the Raman laser beam penetrated into a region of majorite deeper in the sample that is not visible at the surface.

A fourth FIB section was extracted from a Na-, Ca-, Al-rich phase, which was identified as jadeite-lingunite based on the Raman spectra (Figs. 3 and 8). This phase is embedded in majorite, an occurrence that appears to be typical of other jadeite-lingunite grains (Fig. 8a). Two different minerals were identified within the FIB section. Ca-poor majorite was identified based on EDS analyses and electron diffraction patterns, and consists of equant crystals of sizes around $0.5 \mu \mathrm{m}$ (Fig. 8b,g). We also identified a porous vein $\sim 1 \mu \mathrm{m}$ wide that crosscuts the coarse crystalline majorite. Most of the FIB section consists of nanocrystalline lingunite that occurs in two distinct regions with two different grain sizes (marked as 1 and 2 in Fig. 8b), <100 nm, and <10 nm, respectively, separated by a distinct boundary. Fast Fourier Transforms (FFTs) obtained from high-resolution TEM images and diffraction patterns from both regions of nanocrystallites show that it has the hollandite-structure of Na-plagioclase (lingunite) (Fig. 8c-f).

Fig. 8.

\subsection{The matrix}

The matrix of the shock vein is complex and consists of several different phases. Raman spectra obtained from the matrix show the two characteristic Raman bands at 674 $\mathrm{cm}^{-1}$ and $933 \mathrm{~cm}^{-1}$ from majorite-pyrope (Fig. 3). However, the $674 \mathrm{~cm}^{-1}$ peak could also correspond to $\mathrm{MgSiO}_{3}$ pyroxene glass (Kubicki et al. 1992; Imae and Ikeda 2010) or vitrified $\mathrm{MgSiO}_{3}$-perovskite (Durben and Wolf 1992). The matrix in the larger SMV consists of equant and/or euhedral isotropic Ca-rich majorite-pyrope ${ }_{s s}$ with grain sizes of 3-5 $\mu \mathrm{m}$ (Fig. 9, Table 1). The majorite-pyrope garnets are rich in $\mathrm{Al}_{2} \mathrm{O}_{3}, \mathrm{CaO}, \mathrm{Na}_{2} \mathrm{O}$, and $\mathrm{Cr}_{2} \mathrm{O}_{3}$. The matrix is dominated by a cellular texture, although other textures such as microporphyritic are also observed in many regions of both veins and melt pockets (e.g., Fig. 9a,b). Ferropericlase grains $<\sim 1 \mu \mathrm{m}$ in size are also found filling interstices between the majorite-pyrope (Fig. 9c). The ferropericlase occurs as rounded grains, either isolated or in clusters, similar to those reported by Fritz and Greshake (2009) in the Chassigny meteorite and Chen et al. (1996) in the Sixiangkou L5 ordinary chondrite. The clusters of ferropericlase are embedded within a glassy phase that has lower BSE contrast (Fig. 9c). In 
some areas of the matrix, the interstices between grains are filled with a phase enriched in Fe and S, associated with crystallization from a melt of a mixture of majorite-pyrope and troilite.

Backscattered electron imaging shows that in some areas of the matrix the majoritepyrope grains show compositional zoning, which is apparent as distinct lower $\mathrm{Z}$ rims $\sim 0.5$ $1 \mu \mathrm{m}$ thick due to a higher concentration of $\mathrm{MgO}$ (Fig. 9d). Some grains also have Mg-rich cores $(2-3 \mu \mathrm{m})$ (Fig. 9d); it seems most likely that all the grains have Mg-rich cores, but the centers of the grains are not exposed at the surface of the sample. These observations represent the first reported evidence of zoning in garnet in a matrix of a shocked melt vein and suggests crystallization from a melt that occurred too rapidly to allow the grains to equilibrate due to very high cooling rates. Metal-troilite blebs with sizes ranging from few microns to $\sim 50 \mu \mathrm{m}$ are commonly found in some regions of the matrix and can be very abundant or even dominate the matrix (Fig. 9a). Many metal-troilite blebs are zoned with metal concentrated at the core and troilite at the rims, and their textures vary from rounded (Fig. 9b) to irregularly shaped (Fig. 9a).

\section{Fig. 9.}

\section{Discussion}

Although there have been several studies of shock features in ordinary chondrites (e.g., Xie et al. 2006; Xie and Sharp 2007; Ozawa et al. 2009; Miyahara et al. 2010; Tomioka et al. 2016), in the present work we report new observations made in a large shock melt vein of our sample of the host L6 chondrite of the Villalbeto de la Peña polymict chondritic breccia, which provide additional insights into high-pressure phase transformations, in particular the behavior of diopside. Although diopside is ubiquitous in ordinary chondrites, it is much less abundant (between 5.7-8.8\%, Dunn et al. 2010) than the major silicate phases, olivine and low-Ca pyroxene. Calcium-rich majorite, its highpressure polymorph, is thus rarely found in ordinary chondrites (Tomioka and Kimura 2003; Xie et al. 2006). The stability of diopside during shock metamorphism has been mainly studied using high-pressure experiments at high temperatures $\left(>1000^{\circ} \mathrm{C}\right)(\mathrm{e} . \mathrm{g}$., 
Canil 1994; Gasparik 1990; Oguri et al. 1997; Irifune et al. 2000; Akaogi et al. 2004; Asahara et al. 2005) and therefore, its transformation behavior as a result of shock is comparatively poorly understood.

In the present work, we report the third occurrence of Ca-rich majorite in an ordinary chondrite, but our main contribution is to understand the shock-induced transformations of diopside. We distinguish three different behaviors for diopside, which indicate different shock conditions: (1) diopside transformed to Ca-rich majorite, (2) single crystals of Ca-rich majorite undergoing a transformation to a symplectic intergrowth of $\mathrm{Ca}$ poor majorite and Ca-rich glass, and (3) diopside undergoing direct melting without transforming to a high-pressure phase.

The first two transformation behaviors of diopside are observed within the same grain studied by TEM, which was taken from the thinner part of the vein. First, diopside is transformed to single crystals of Ca-rich majorite through a solid-state phase transformation since its composition is identical to the diopside in the host rock. The Ca-rich majorite might have tetragonal symmetry seen by the optical anisotropy and the presence of several reflections in electron diffraction patterns, for example, the $(0 k l)$ reflections where $(k, l=$ odd) in the [211] zone axis, but as we have mentioned in the results section, these reflections can also appear due to multiple diffraction effects in the cubic structure. Second, and counter to previous studies by Xie and Sharp (2007), the single crystal is, in turn, dissociated into a symplectic intergrowth of $\mathrm{Ca}$-poor majorite plus $\mathrm{Ca}$-rich glass. The $\mathrm{Ca}-$ rich glass is interpreted to be Ca-perovskite that vitrified under decompression similar to the example seen in the Shergotty Martian meteorite (Tomioka and Kimura 2003), the first meteorite where Ca-rich majorite was reported (Malavergne et al. 2001). In Shergotty, the majorite and the Ca-rich glass have a granular texture and are complementary in composition to one another. According to high-pressure experiments on $\mathrm{CaSiO}_{3}$, a phase with the perovskite structure is stable above $\sim 23 \mathrm{GPa}$ and $\sim 1000^{\circ} \mathrm{C}$, but it progressively transforms into glass during decompression (Liu and Ringwood 1975; Liu 1987). Another possibility is that the symplectite crystallized from a pyroxene melt, but more extensive work would be needed to constrain this alternative explanation. The two different transformation behaviors that we have found in the same Ca-rich majorite grain are 
interpreted as a temporal sequence, starting with the solid-state high-pressure transformation of diopside to Ca-rich majorite, and followed by dissociation and/or melting of the Ca-rich majorite. The majorite in the symplectite has the same crystallographic orientation as the large single crystal that it formed from, suggesting that the dissociation reaction does not necessarily involve nucleation and growth of new majorite crystals, but retains the structural elements of the precursor phase. The dissociation was incomplete, likely due to a fast shock duration and/or large grain sizes. These grains are also fractureless and smooth seen under SEM at high magnification, suggesting no evidence of a fine-grained structure.

Diopside examined by TEM from a wider region of the shock vein is found within a large entrained chondrule fragment surrounded by matrix with abundant FeNi-troilite blebs, and shows a completely different behavior. In this case, diopside underwent direct shockinduced melting, since an amorphous phase with exactly the same diopside composition surrounds the crystal, which we interpret as quenched glass. The magnesiowüstite veins are crystallographically oriented in the diopside, but are absent within the glass phase. Rather, porosity in the glass is continuous from the magnesiowüstite veins (Fig. 6c), suggesting that magnesiowüstite, as a melt, was injected into the diopside at the same time diopside was undergoing melting. One possible explanation for the porosity in the glass that is coincident with the termination of the veins is that the magnesiowüstite melt contained a gaseous phase when it was injected into the diopside, which could have helped reduce the viscosity of the melt and hence, allowing it to travel further. The gas escaped into the diopside melt as the magnesiowüstite veins crystallized, but before the diopside melt quenched, i.e. occurred at high temperature. This is consistent with the numerous fractures seen within the magnesiowüstite veins and the presence of porosity in the melt phase (Fig. 6c). We interpret this whole scenario as evidence of a very fast, but intense shock event within this particular region of the vein. Temperature could have been higher than in the thinner region of the vein according to the phase diagram of diopside. The presence of magnesiowüstite veins in a shocked chondrite has not been described previously. The formation of a melt with primarily magnesiowüstite composition that injects into diopside is interpreted as the residual fractionated product of a melt vein matrix that crystallized majorite-pyrope grains (see below). 
In this study, we have also found the first evidence of compositional zoning at an extremely fine scale in the majorite-pyrope grains that dominate the matrix of the widest region of the shock vein. The $\mathrm{Mg}$-rich cores of the majorite-pyrope grains are consistent with the experimental silicate-melt partitioning data for crystallization of majorite (Drake et al. 1993). As cooling takes place, both the majorite-pyrope crystals and the melt become Fe-rich, but the partition coefficient requires the melt to be more Fe-enriched than the crystals. We attribute the observed change in $\mathrm{Mg} / \mathrm{Fe}$ ratio in majorite-pyrope crystals to the crystallization of micron-sized clusters of magnesiowüstite in the interstitial residual melt, which depletes the melt in Fe and, therefore, the Fe content in the majorite-pyrope crystals drops and becomes more Mg-rich (Fig. 9c,d). The rate of Mg-Fe interdiffusion in majoritepyrope is much slower than, for example, in olivine (Van Mierlo et al. 2013). Therefore, fast cooling rates are not necessary to preserve the compositional zonation and prevent equilibration. Nevertheless, fast cooling rates within the wider region of the shock vein are clearly indicated by: a) the very fine-grained texture of the melt vein, and b) the presence of quenched diopside glass within a chondrule fragment, as discussed above.

In order to estimate the peak shock conditions at which the main shock melt vein of Villalbeto de la Peña crystallized, we have used the following constraints (i) the experiments performed by Akaogi et al. (2004) on diopside, which show that the assemblage of majorite plus vitrified Ca-rich perovskite is stable at $\sim 17-24 \mathrm{GPa}$ and $\sim 1500$ $2200^{\circ} \mathrm{C}$, (ii) the tetragonal majorite stability field determined by experiments on enstatite $\left(\mathrm{MgSiO}_{3}\right)($ Gasparik 1990), and (iii) the jadeite-lingunite stability field boundary based on Akaogi (1989). Our estimated P-T conditions for the shock vein are shown in Figure 10. The pressures indicated by the high-pressure transformation behavior of diopside range from 16-17 GPa for direct melting (green oval in Fig. 10), to 17-24 GPa, indicated by the transformation of diopside into majorite (red oval in Fig. 10). The occurrence of jadeitelingunite assemblages in the shock vein suggests pressures $\geq 19 \mathrm{GPa}$, since the jadeite detected with Raman spectroscopy can be interpreted as the decompression product of lingunite during pressure release. In comparison, melting of magnesiowüstite with a composition of $\mathrm{MgO}_{9} \mathrm{FeO}_{91}$ (i.e., closer to pure wüstite) is estimated to occur at $\sim 28 \mathrm{GPa}$ at the temperature that diopside undergoes melting $\left(2200^{\circ} \mathrm{C}\right)$ (Boehler 1992; Zerr and Boehler 1994; Fisher and Campbell 2010). Based on these experimental constraints, the elevated 
pressure required for magnesiowüstite melting is difficult to reconcile with the lower pressures indicated by the melting of diopside, unless we consider that pressures can be significantly higher in very localized regions of the vein (i.e. matrix) and hence, more variable than previously predicted. Such heterogeneity in peak shock pressures is very likely the result of localized microporosity within the meteorite, differences in shock impedance between adjacent minerals or reverberation of shock waves across grain boundaries (e.g., Bischoff and Stöffler 1992; Sharp and de Carli 2006). If this explanation is correct, it further underscores the challenges of efforts to constrain peak shock pressures based on high-pressure mineral phase transformations, particularly when observations are made at the micron to submicron scale using TEM techniques. Although the peak shock pressures are clearly variable on a localized scale, the constraints on temperature are much more consistent. The observed phase transformations in different regions of the vein could all occur at similar temperatures, which is estimated to be around $2000-2200^{\circ} \mathrm{C}$ (Fig. 10), based on the phase diagram constraints.

\section{Fig. 10.}

Another important caveat is that the experimental phase diagrams we have used to estimate the peak shock conditions may not accurately reflect the behavior of the natural system due to compositional differences and faster cooling rates in the meteoritic samples than those performed in experiments. For example, it is known that an increase in FeO in a solid solution of a given phase lowers the melting temperature (Agee et al. 1995). Furthermore, based on kinetic data obtained on albite under static conditions (Kubo et al. 2008), and experiments using internally laser-heated Mao-Bell type diamond anvil cells between 15 and $30 \mathrm{GPa}$ (Tutti 2007), the lingunite phase suggests pressures between 20.5 to $24 \mathrm{GPa}$ if the duration of the shock event is 1 second or more. However, if the shock event that formed the shocked vein in Villalbeto lasted $<1$ second, then lingunite could have crystallized at higher P-T conditions, consistent with pressures required for a wüstite melt. The incomplete dissociation of Ca-majorite into a symplectic intergrowth of Ca-poor majorite plus Ca-rich glass also supports very fast cooling rates. Although we do not have experimental data to quantify the cooling rate, we conclude that the shock melt vein of Villalbeto crystallized at a very fast duration based on TEM observations. 


\section{Conclusions}

There are very few descriptions of the effects of shock in diopside in ordinary chondrites, possibly due to relatively low modal abundances of diopside (between 5.78.8\%, Dunn et al. 2010). However, in this study we have gained new insights into the highpressure shock behavior of diopside that have not been reported previously. The discovery of shocked transformed diopside in Villalbeto may be attributable to the fact that the vein studied is unusually large, and therefore a larger volume of target material has been affected.

Specifically, we have observed three different types of shock transformation mechanisms for diopside under high-pressure and temperature conditions. We have observed the occurrence of the solid-state transformation of diopside into Ca-rich majorite in the thinner region of the vein. The Ca-rich majorite is, in turn, dissociated into a symplectic intergrowth of Ca-poor majorite and Ca-rich glass. In addition, we have also observed the first example of diopside undergoing direct melting in a wider region of the SMV.

Majorite-pyrope grains have been previously described in the matrix of shock veins in other shocked ordinary chondrites (e.g., Chen et al. 1996; Miyahara et al. 2010), but are compositionally homogeneous. In this study, we report the occurrence of compositionallyzoned majorite-pyrope grains, with Mg-rich cores zoned to more Fe-rich compositions outwards, plus Mg-rich overgrowth rims. This phenomenon has not been reported previously in a matrix of a shock melt vein. However, this observation does not provide a good constraint for the cooling rate of the vein, because diffusion rates in pyrope are very slow.

Constraining the pressure and temperature conditions of the shock melt vein is challenging, because different experimental lines of evidence appear to be contradictory. Temperature can be constrained reasonably well, based on the melting temperature of diopside, to a range between $2000-2200^{\circ} \mathrm{C}$. This temperature variation can be explained by thermal conduction from a shocked-induced melt to a cooler host rock. Pressure might be 
more variable within the shock melt vein than previously predicted for a shock wave travelling through a heterogeneous assemblage of different minerals with different shock impedances and also possibly due to microporosity. For example, the direct melting of diopside indicates pressures of 16-17 GPa, while magnesiowüstite melt that was injected into the diopside must have formed at significantly higher pressures, perhaps as high as 28 GPa based on the data of Boehler (1992). Thus, we conclude that differences in pressure between the matrix (where magnesiowüstite melt forms) and entrained chondrule fragments could have been bigger than previously assumed.

\section{Acknowledgements}

JMT acknowledges funding from grants AYA2011-26522 and AYA2015-67175-P. JL is a Serra Húnter Fellow and is grateful to ICREA Academia program and GC 2017 SGR 128. Additional support for MMJ and AJB was provided by NASA Cosmochemistry grant NNX15AD28G to A. J. Brearley (PI). Special acknowledgements to Narcís Mestres (ICMAB-CSIC) for offering his Raman Spectrometer and providing his guidance. Sample preparation (focused ion beam) and transmission electron microscope analysis were carried out in the Electron Microbeam Analysis Facility in the Department of Earth and Planetary Sciences and Institute of Meteoritics, University of New Mexico.

\section{Bibliography}

Agee C. B., Li J., Shannon M. C., and Circone S. 1995. Pressure- temperature phase diagram for the Allende meteorite. Journal of Geophysical Research: Solid Earth 100:17725-17740.

Akaogi M., Ito E., and Navrotsky A. 1989. Olivine-modified spinel-spinel transitions in the system $\mathrm{Mg}_{2} \mathrm{SiO}_{4}-\mathrm{Fe}_{2} \mathrm{SiO}_{4}$ : calorimetric measurements, thermochemical calculation, and geophysical application. Journal of Geophysical Research 94:15,671-15,685.

Akaogi M., Yano M., Tejima Y., Iijima M., and Kojitani H. 2004. High-pressure transitions of diopside and wollastonite: phase equilibria and thermochemistry of $\mathrm{CaMgSi}_{2} \mathrm{O}_{6}, \mathrm{CaSiO}_{3}$ and $\mathrm{CaSi}_{2} \mathrm{O}_{5}-\mathrm{CaTiSiO}_{5}$ system. Physics of the Earth and Planetary Interiors 143:145-156.

Akaogi M., Haraguchi M., Nakanishi K., Ajiro H., and Kojitani H. 2010. High-pressure phase relations in the system $\mathrm{CaAl}_{4} \mathrm{Si}_{2} \mathrm{O}_{11}-\mathrm{NaAl}_{3} \mathrm{Si}_{3} \mathrm{O}_{11}$ with implication for Na-rich CAS phase in shocked Martian meteorites. Earth and Planetary Science Letters 289:503-508. 
Asahara Y., Ohtani E., Kondo T., Kubo T., Miyajima N., Nagase T., Fujino K., Yagi T., and Kikegawa T. 2005. Formation of metastable cubic-perovskite in high-pressure phase transformation of $\mathrm{Ca}(\mathrm{Mg}, \mathrm{Fe}, \mathrm{Al}) \mathrm{Si}_{2} \mathrm{O}_{6}$. American Mineralogist 90:457-462.

Bischoff A. and Stoffler, D. 1992. Shock metamorphism as a fundamental process in the evolution of planetary bodies: Information from meteorites. European Journal of Mineralogy 4:707-755.

Bischoff A., Dyl K. A., Horstmann M., Ziegler K., Wimmer K., and Young E. D. 2013. Reclassification of Villalbeto de la Peña-Occurrence of a winonaite- related fragment in a hydrothermally metamorphosed polymict L- chondritic breccia. Meteoritics \& Planetary Science 48:628-640.

Boehler, R. (1992). Melting of the FeFeO and the FeFeS Systems at high-pressure: Constraints on core temperatures. Earth and Planetary Science Letters 111:217-227.

Brearley A. J., Casanova I., Miller M. L., and Keil K. 1991. Mineralogy and possible origin of an unusual Cr-rich inclusion in the Los Martinez (L6) chondrite. Meteoritics 26:287-300.

Brearley A. J. and Jones R. H. 1998. Chondritic meteorites. In Planetary Materials, edited by Papike J. J. Reviews in Mineralogy, vol. 36. Washington, D.C.: Mineralogical Society of America. pp. 3.1-3.398.

Bunch T. E., Keil K., and Snetsinger K. G. 1967. Chromite composition in relation to chemistry and texture of ordinary chondrites. Geochimica et Cosmochimica Acta 31:1569-1582.

Canil D. 1994. Stability of clinopyroxene at pressure-temperature conditions of the transition region. Physics of Earth and Planetary Interiors 86:25-34.

Chen, M., and Xie, X. 2008. Two distinct assemblages of high-pressure liquidus phases in shock veins of the Sixiangkou meteorite. Meteoritics and Planetary Science 43:823-828.

Chen M., Sharp T. G., El Goresy A., Wopenka B., and Xie X. 1996. The majoritepyrope+magnesiowüstite assemblage: Constraints on the history of shock veins in chondrites. Science 271:1570-1573.

Chen M., Xie X., Wang D., and Wang S. 2002. Metal-troilite-magnetite assemblage in shock veins of Sixiangkou meteorite. Geochimica et Cosmochimica Acta 66:3143-3149.

Chen M., El Goresy A., and Gillet P. 2004. Ringwoodite lamellae in olivine: Clues to olivineringwoodite phase transition mechanisms in shocked meteorites and subducting slabs. Proceedings of the National Academy of Sciences 101:15033-15037.

Chen M., Li H., El Goresy A., Liu J., and Xie X. 2006. Fracture-related intracrystalline transformation of olivine to ringwoodite in the shocked Sixiangkou meteorite. Meteoritics \& Planetary Science 41:731-737.

Chen M., Chen J., Xie X., and Xu J. 2007. A microstructural investigation of natural lamellar ringwoodite in olivine of the shocked Sixiangkou chondrite. Earth and Planetary Science Letters 264:277-283.

Coleman L. C. 1977. Ringwoodite and majorite in the Catherwood meteorite. Canadian Mineralogist 15:97-101.

Chopelas A., and Serghiou G. 2002. Spectroscopic evidence for pressure-induced phase transitions in diopside. Physics and Chemistry of Minerals 29:403-408.

Drake M. J., McFarlane E. A., Gasparik T., and Rubie D. C. 1993. Mg- perovskite/silicate melt and majorite garnet/silicate melt partition coefficients in the SYSTEM CaO- $\mathrm{MgO}-\mathrm{SiO}_{2}$ at high temperatures and pressures. Journal of Geophysical Research: Planets 98:5427-5431.

Dunn T. L., Cressey G., McSween Jr H. Y., and McCoy, T. J. 2010. Analysis of ordinary chondrites using powder X- ray diffraction: 1. Modal mineral abundances. Meteoritics \& Planetary Science 45:123-134. 
Durben D. J. and Wolf G. H. 1992. High-temperature behavior of metastable $\mathrm{MgSiO}_{3}$ perovskite. American Mineralogist 77:890-893.

Feng L., Lin Y., Hu S., Xu L., and Miao B. 2011. Estimating the composition of natural ringwoodite in the heavily shocked Grove Mountains 052049 meteorite from Raman spectra. American Mineralogist 96:1480-1489.

Fischer, R. A. and Campbell, A. J. 2010. High-pressure melting of wüstite. American Mineralogist 95:1473-1477.

Fritz J. and Greshake A. 2009. High-pressure phases in an ultramafic rock from Mars. Earth and Planetary Science Letters 288:619-623.

Gasparik T. 1990. Phase relations in the transition zone. Journal of Geophysical Research 95:15751-15769.

Gillet P., El Goresy A., Beck P., and Chen M. 2007. High-pressure mineral assemblages in shocked meteorites and shocked terrestrial rocks: mechanisms of phase transformations and constraints to pressure and temperature histories. Geological Society of America Special Papers 421:57-82.

Imae N. and Ikeda Y. 2010. High- pressure polymorphs of magnesian orthopyroxene from a shock vein in the Yamato- 000047 lherzolitic shergottite. Meteoritics \& Planetary Science 45:43-54.

Irifune T., Miyashita M., Inoue T., Ando J., Funakoshi K., and Utsumi W. 2000. High-pressure phase transformation in $\mathrm{CaMgSi}_{2} \mathrm{O}_{6}$ and implications for origin of ultra-deep diamond inclusions. Geophysical Research Letters 27:3541-3544.

Kubicki J. D., Hemley R. J., Hofmeister A. M. 1992. Raman and infrared study of pressure-induced structural changes in $\mathrm{MgSiO}_{3}, \mathrm{CaMgSi}_{2} \mathrm{O}_{6}$, and $\mathrm{CaSiO}_{3}$ glasses. American Mineralogist 77:258-269.

Kubo T., Kimura M., Nishi M., Tominaga A., Kato T., Kikegawa T., Funakoshi K., and Miyahara M. 2008. Formation of jadeite from plagioclase: Constraints on the P-T-t conditions of shocked meteorites. Meteoritics \& Planetary Science 43:A82.

Lafuente B., Downs R. T.. Yang H., and Stone N. 2015. The power of databases. The RRUFF project. In Highlights in Mineralogical Crystallography, edited by Armbruster T., and Danisi R. M., Berlin: W. De Gruyter, pp 1-30.

Langenhorst F., Joreau P., and Doukhan J. C. 1995. Thermal and shock metamorphism of the Tenham chondrite: a TEM examination. Geochimica et Cosmochimica Acta 59:1835-1845.

Liu L. 1987. New silicate perovskites. Geophysical Research Letters 14:1079-1082.

Liu L. and Ringwood A. E. 1975. Synthesis of a perovskite-type polymorph of $\mathrm{CaSiO}_{3}$. Earth and Planetary Science Letters 28:209-211.

Llorca J., Trigo-Rodríguez J. M., Ortiz J. L., Docobo J. A., Garcia-Guinea J., Castro-Tirado A. J., Rubin A. E., Eugster O., Edwards W., Laubenstein M., and Casanova I. 2005. The Villalbeto de la Peña meteorite fall. I. Fireball energy, meteorite recovery, strewn field, and petrography. Meteoritics \& Planetary Science 40:795-804.

Llorca J., Gich M., and Molins E. 2007. The Villalbeto de la Peña meteorite fall. III. Bulk chemistry, porosity, magnetic properties, ${ }^{57} \mathrm{Fe}$ Mössbauer spectroscopy, and Raman spectroscopy. Meteoritics \& Planetary Science 42:A117-A182.

Ma C., Tchauner O., Beckett J. R., Liu Y., Rossman G. R., Zhuravlev K., Prakapenka V., Dera P., Taylor L. A. 2015. Tissintite, $(\mathrm{Ca}, \mathrm{Na}, \square) \mathrm{AlSi}_{2} \mathrm{O}_{6}$, a highly defective, shock-induced, highpressure clinopyroxene in the Tissint martian meteorite. Earth and Planetary Science Letters 422:194-205. 
Malavergne V., Guyot F., Benzerara K., and Martinez I. 2001. Description of new shock induce phases in the Shergotty, Zagami, Nakhla and Chassigny meteorites. Meteoritics \& Planetary Science 36:1297-1305.

Martínez-Jiménez M. and Brearley A. J. 2017. Phase transformation mechanisms of Ca-majorite in the shocked Villalbeto de la Peña ordinary chondrite: Clues to cooling paths in shocked meteorites (abstract \#6160). 80th Annual Meeting of the Meteoritical Society. Meteoritics \& Planetary Science 52.

Miyahara M., Goresy A. E., Ohtani E., Nagase T., Nishijima M., Vashaei Z., Ferroir T., Gillet P., Dubrovinsky L, and Simionovici A. 2008. Evidence for fractional crystallization of wadsleyite and ringwoodite from olivine melts in chondrules entrained in shock-melt veins. Proceedings of the National Academy of Sciences 105:8542-8547.

Miyahara M., Ohtani E., Kimura M., El Goresy A., Ozawa S., Nagase T., Nishikima M., and Hiraga K. 2010. Coherent and subsequent incoherent ringwoodite growth in olivine of shocked L6 chondrites. Earth and Planetary Science Letters 295:321-327.

Miyahara M., Ohtani E., Ozawa S., Kimura M., El Goresy A., Sakai T., and Ohishi Y. 2011. Natural dissociation of olivine to $(\mathrm{Mg}, \mathrm{Fe}) \mathrm{SiO}_{3}$ perovskite and magnesiowüstite in a shocked Martian meteorite. Proceedings of the National Academy of Sciences 108:5999-6003.

Oguri K., Funamori N., Skai F., Kondo T., Uchida T., and Yagi T. 1997. High-pressure and hightemperature phase relations in diopside $\mathrm{CaMgSi}_{2} \mathrm{O}_{6}$. Physics of the Earth and Planetary Interiors 104:363-370.

Ohtani E., Kimura Y., Kimura M., Takata T., Kondo T., and Kubo T. 2004. Formation of highpressure minerals in shocked L6 chondrite Yamato 791384: Constraints on shock conditions and parent body size. Earth and Planetary Science Letters 227:505-515.

Ozawa S., Ohtani E., Miyahara M., Suzuki A., Kimura M., and Ito Y. 2009. Transformation textures, mechanisms of formation of high- pressure minerals in shock melt veins of L6 chondrites, and pressure- temperature conditions of the shock events. Meteoritics \& Planetary Science 44:1771-1786.

Ribbe P. H. and Smith J. V. 1966. X-ray-emission microanalysis of rock-forming minerals: IV. Plagioclase. The Journal of Geology 74:217-233.

Sharp T. G., Lingemann C. M., Dupas C., and Stöffler D. 1997. Natural occurrence of $\mathrm{MgSiO}_{3}-$ ilmenite and evidence for $\mathrm{MgSiO}_{3}$-perovskite in a shocked L chondrite. Science 277:352-355.

Sharp T. G., and DeCarli P. S. 2006. Shock effects in meteorites. In Meteorites and the Early Solar System II, edited by Lauretta, D. S. and McSween H. Y. Jr. Tucson, Arizona: University of Arizona Press. pp. 653-677.

Spray J. G. and Rae D. A. 1995. Quantitative electron-microprobe analysis of alkali silicate glasses: A review and user guide. Canadian Mineralogist 33:323-332.

Stöffler D., Keil K., and Scott E. R. D. 1991. Shock metamorphism of ordinary chondrites. Geochimica et Cosmochimica Acta 55:3845-3867.

Tomioka, N. and Fujino, K. 1997. Natural (Mg,Fe)SiO 3 -ilmenite and-perovskite in the Tenham meteorite. Science 277:1084-1086.

Tomioka N. and Kimura M. 2003. The breakdown of diopside to Ca-rich majorite and glass in shocked H chondrite. Earth and Planetary Science Letters 208:271-278.

Tomioka N., Miyahara M., and Ito M. 2016. Discovery of the natural $\mathrm{MgSiO}_{3}$ tetragonal garnet in a shocked chondritic meteorite. Science Advances 2(3), doi: 10.1126/sciadv.1501725. 
Tschauner O., Ma C., Beckett J. R., Prescher C., Prakapenka V. B., and Rossman G. R. 2014. Discovery of bridgmanite, the most abundant mineral in Earth, in a shocked meteorite. Science 346:1100-1102.

Tutti F. 2007. Formation of end-member $\mathrm{NaAlSi}_{3} \mathrm{O}_{8}$ hollandite-type structure (lingunite) in diamond anvil cell. Physics of the Earth and Planetary Interiors 161:143-149.

Van Mierlo W. L., Langenhorst F., Frost D. J., and Rubie D. C. 2013. Stagnation of subducting slabs in the transition zone due to slow diffusion in majoritic garnet. Nature Geoscience 6:400.

Xie Z. and Sharp T. G. 2007. Host rock solid-state transformation in a shock-induced melt vein of Tenham L6 chondrite. Earth and Planetary Science Letters 254:433-445.

Xie X., Sharp T. G., and DeCarli P. S. 2006. High-pressure phases in a shock-induced melt vein of the Tenham L6 chondrite: Constraints on shock pressure and duration. Geochimica et Cosmochimica Acta 70:504-515.

Zerr, A. and Boehler, R. 1994. Constraints on the melting temperature of the lower mantle from high-pressure experiments on $\mathrm{MgO}$ and magnesioüstite. Nature 371:506-508.

Zhang A., Hsu W., Wang R., and Ding M. 2006. Pyroxene polymorphs in melt veins of the heavily shocked Sixiangkou L6 chondrite. European Journal of Mineralogy 18:719-726. 


\section{Figures}
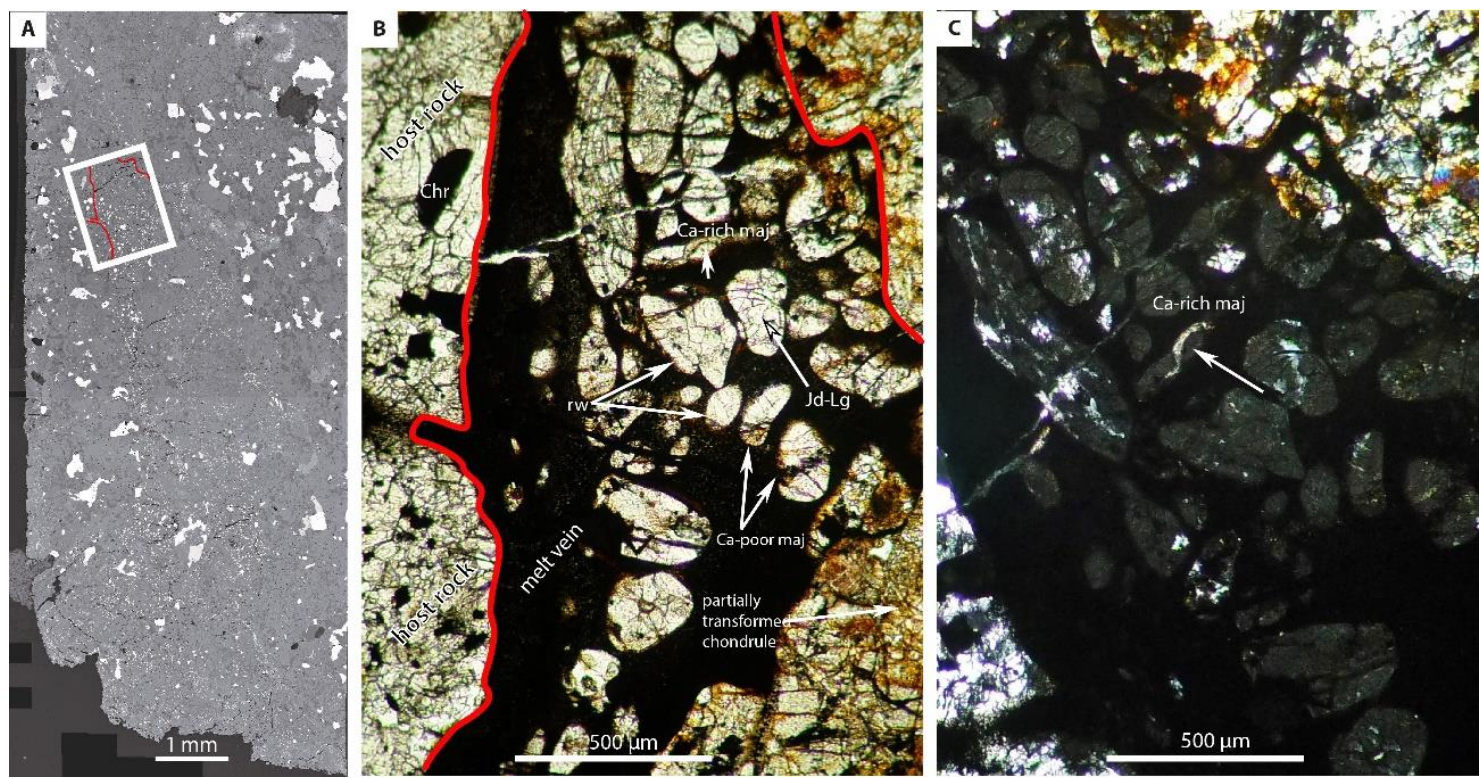

Fig. 1. a) Backscattered electron (BSE) mosaic of the studied shock melt vein; b) and c)

Transmitted and plane-polarized light images, respectively, of the upper and thinner part of the main shock melt vein in Villalbeto where entrained fragments are aligned and completely transformed to their high-pressure polymorphs. Legend: $\mathrm{Ca}$-rich maj $=\mathrm{Ca}-$ rich majorite; $\mathrm{rw}=$ ringwoodite; $\mathrm{Jd}-\mathrm{Lg}=$ jadeite-lingunite Ca-poor maj $=\mathrm{Ca}$-poor majorite; $\mathrm{Chr}=$ chromite. The red line delineates the boundary between the host rock and the vein. 

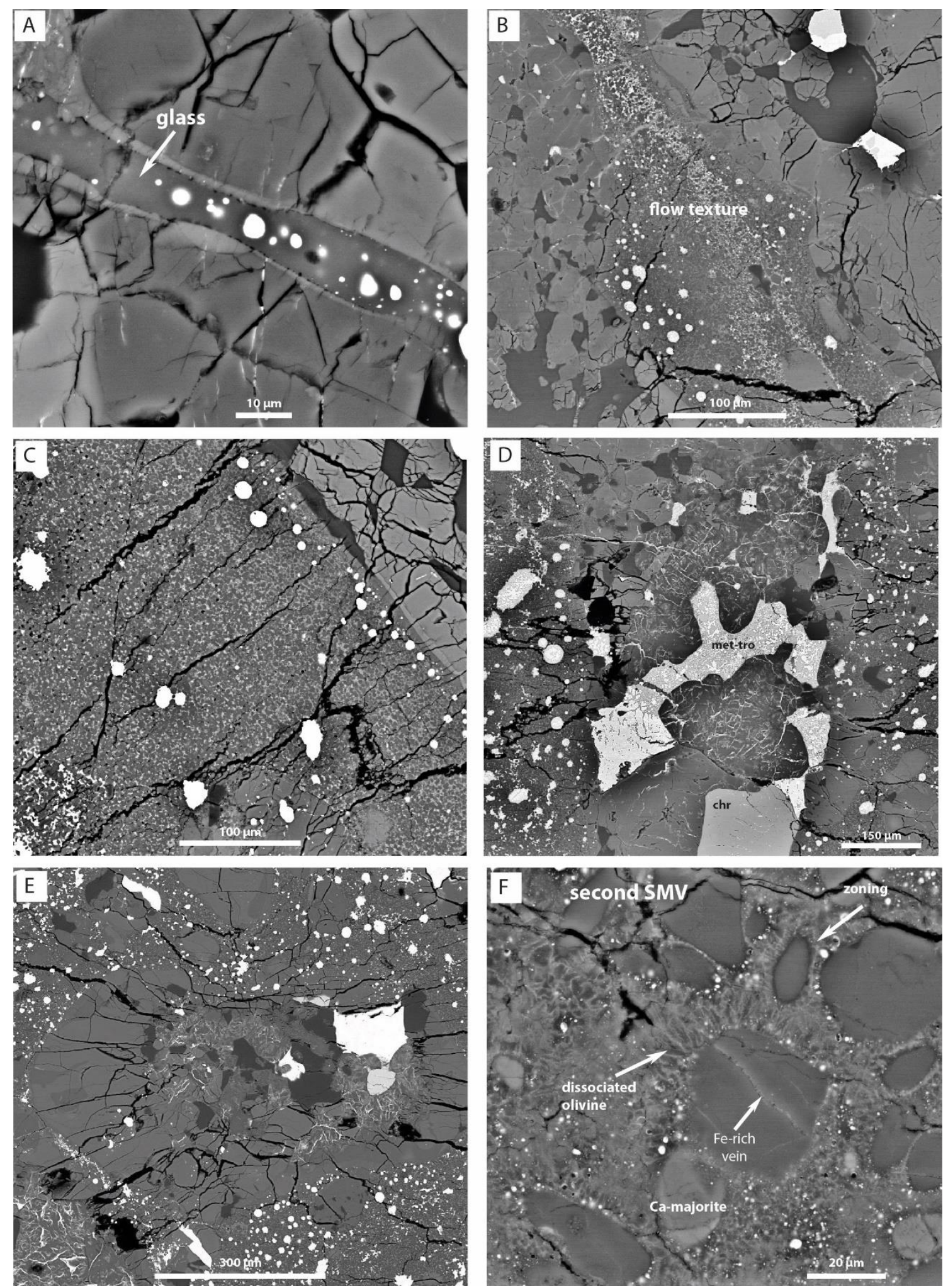

Fig 2. Backscattered electron (BSE) images of shock melt veins in Villalbeto de la Peña. a) A very thin vein of glass and metal-troilite. b) Flow texture in a region of the main vein characterized by elongated clasts oriented in the same direction, and a flowtextured matrix around them. c) Matrix of a region of the main vein. Rounded metaltroilite blebs dominate the edges of the vein, and irregularly-shaped metal-troilite blebs, 
the interior. d) Large metal-troilite grains in the vein associated with large chromite grains with exsolved troilite features. e) Shock texture consisting of troilite filling radial fractures within a large chondrule, probably due to injection of a troilite shock melt. f) Portion of the second shock melt vein (SMV) with partially dissociated olivine, Camajorite, compositionally-zoned mineral fragments, probably ringwoodite, with metal droplets around them. 

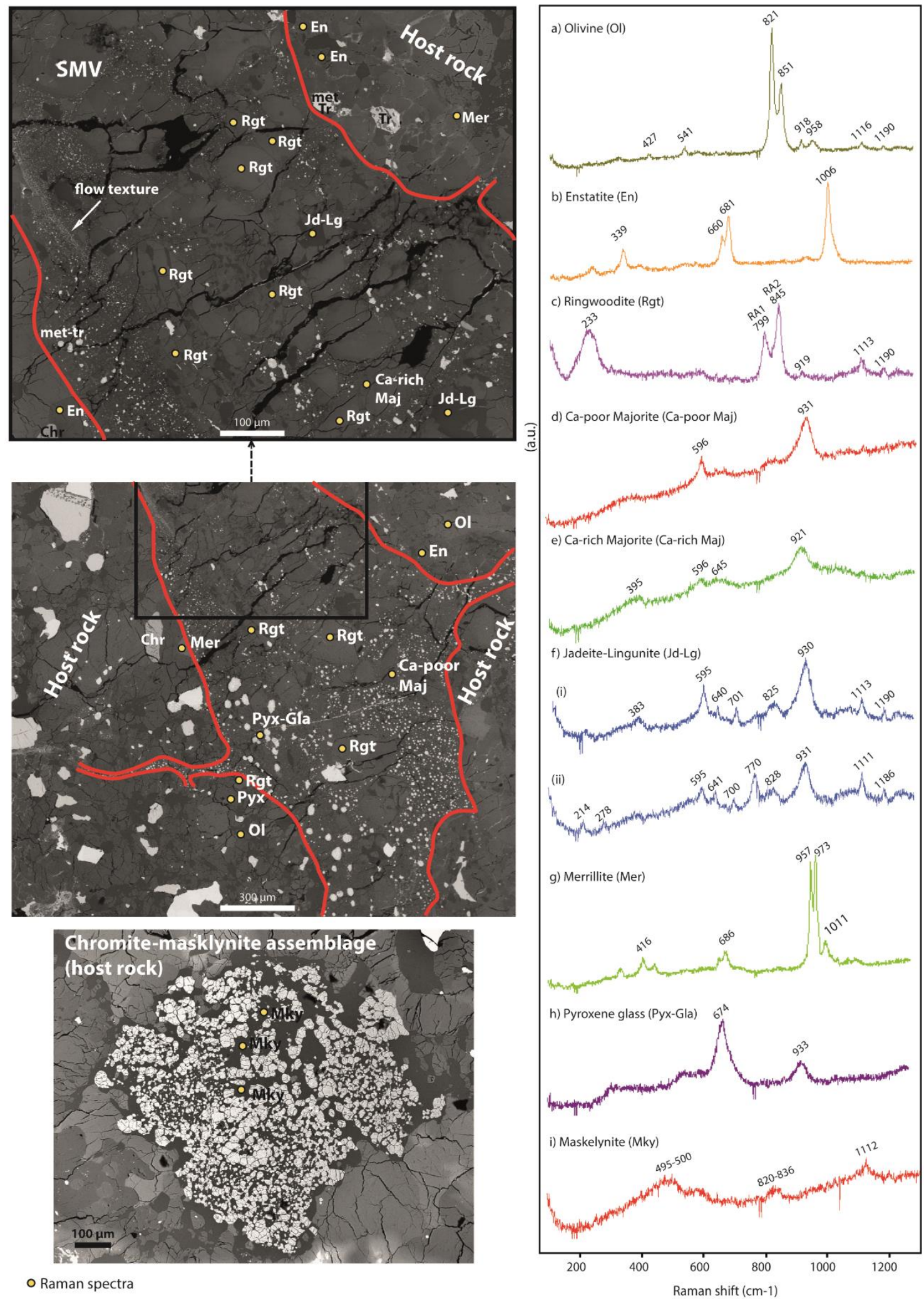

Fig. 3. Top and center on the left: Backscattered electron (BSE) images of the shock vein showing the locations of some of the Raman measurements. Bottom on the left: BSE image of a chromite-maskelynite assemblage $(\sim 80 \mu \mu \mathrm{m}$ size $)$ from the host rock with its corresponding Raman measurements. Legend: $\mathrm{Ol}=$ olivine; En = enstatite (low- 
Ca pyx); Rgt = ringwoodite; Jd-lg = jadeite-lingunite; Ca-rich maj = Ca-rich majorite; Ca-poor maj $=\mathrm{Ca}$-poor majorite Mer $=$ merrillite Met $=\mathrm{FeNi} ; \mathrm{Tr}=$ troilite $\mathrm{Chr}=$ chromite. Right: Raman spectra of the main minerals found in the thinner part of the vein.
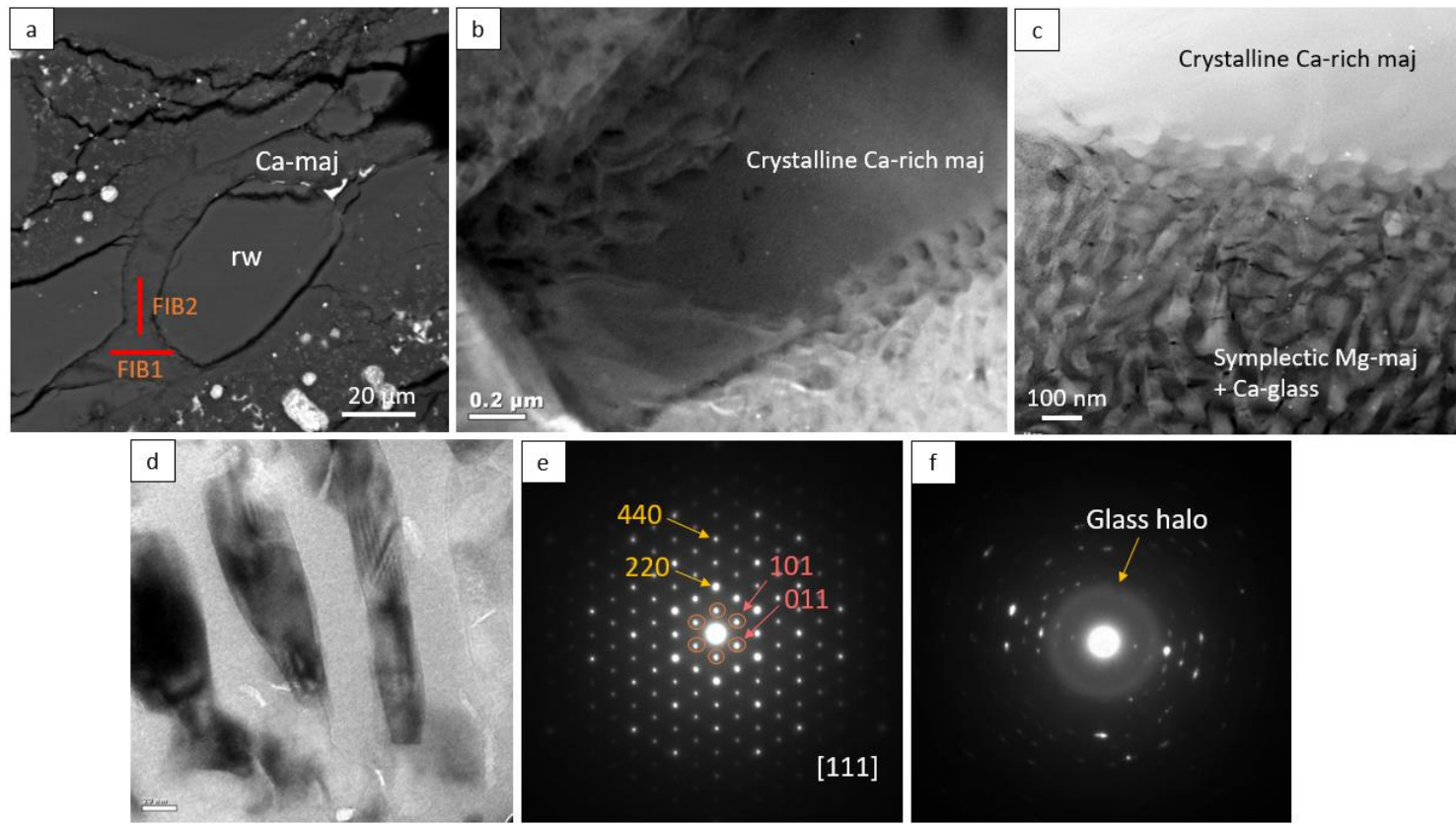

Fig. 4. SEM and TEM images of the Ca-rich majorite studied in the main vein of Villalbeto. a) BSE image of the Ca-rich majorite (Ca-maj) associated with ringwoodite (rw) in the SMV showing the locations of the two FIB sections extracted from the sample. b) Bright-field TEM image of a crystalline Ca-rich majorite undergoing a symplectic dissociation at its margins. c) Higher magnification image of the symplectic Mg-rich majorite plus Ca-rich glass. d) Bright-field TEM image at higher magnification of the symplectic wormy Ca-poor majorite crystals (dark gray) showing some lattice fringes, and the glass (light gray). e) [111] zone axis diffraction pattern of the single crystal in (b) showing the presence of reflections $\{h O l\}$ where $(h, l=$ odd) (circled in red on the diffraction pattern), which are absent in the cubic structure and therefore could be indicative of tetragonal symmetry (space group $I 4_{1} / a$ ). However, these reflections can occur due to double diffraction and thus, they are not diagnostic of tetragonal symmetry. f) Diffraction pattern showing a diffuse ring indicative of an amorphous material. Arcing of the diffraction maxima for the Ca-rich majorite crystals in the symplectite are also present indicative of crystallites that are slightly misoriented, but overall have the 
same crystallographic orientation as the single crystal of Ca-rich majorite that they surround.
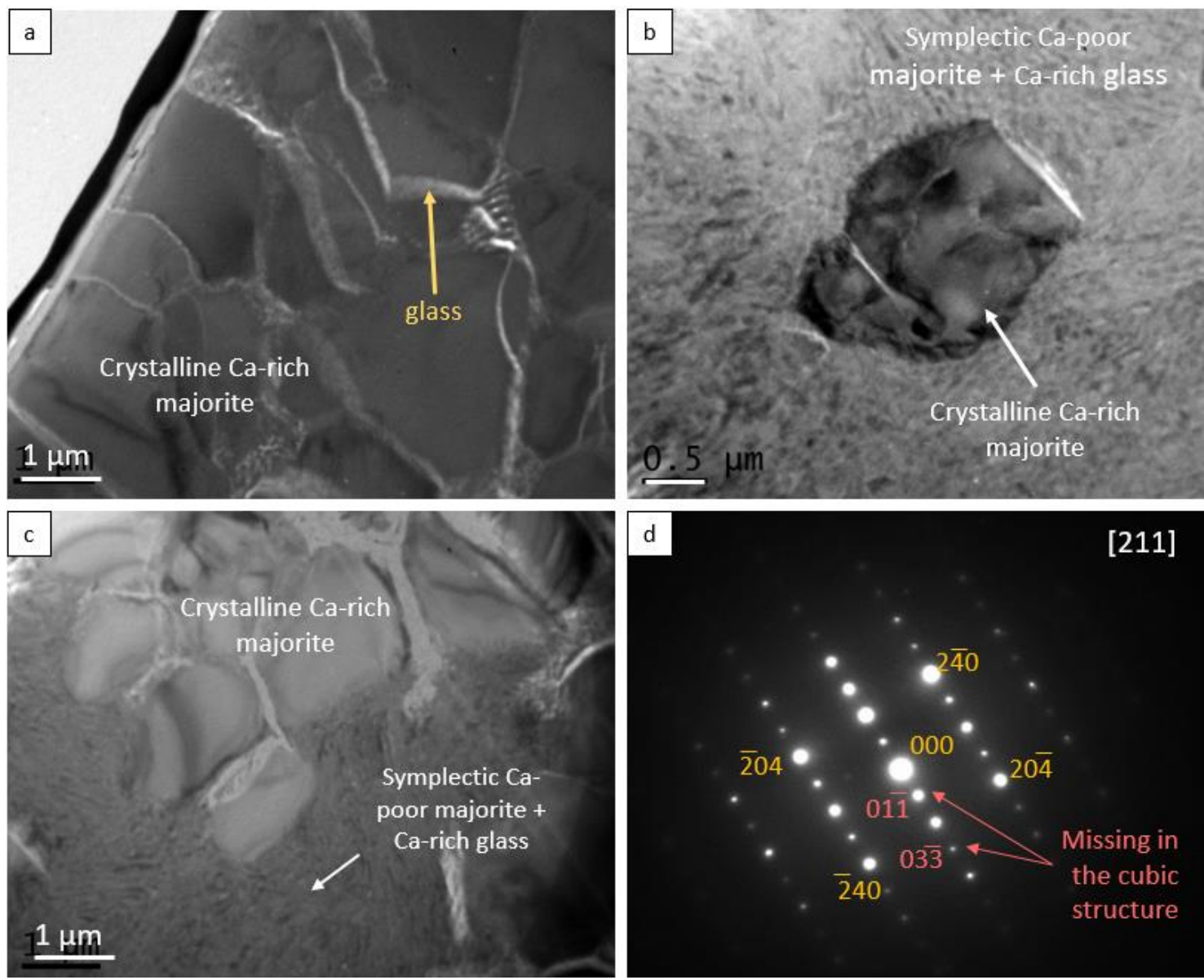

Fig. 5. Bright-field TEM images from the FIB2 TEM section marked in Fig. 4a.

a) Crystalline Ca-rich majorite consisting of multiple subgrains of $\sim 1-2 \mu \mathrm{m}$ size with possible glass at the grain boundaries, which could represent the earliest stages of symplectite intergrowth development along the grain boundaries. b) A subrounded single crystal of Ca-rich majorite embedded within a symplectic intergrowth of Ca-poor majorite plus Ca-rich glass. The single crystal consists of several subgrains shown by the strain contrast in it. c) Other crystalline grains embedded in the symplectic Ca-poor majorite plus Ca-rich glass similar to FIB1 (Fig. 4). d) Diffraction pattern of the Ca-rich majorite on the [211] zone axis showing the presence of $\{0 k l\}$ where $(k, l=$ odd), which could be indicative of tetragonal symmetry or appear due to double diffraction in the cubic structure. 


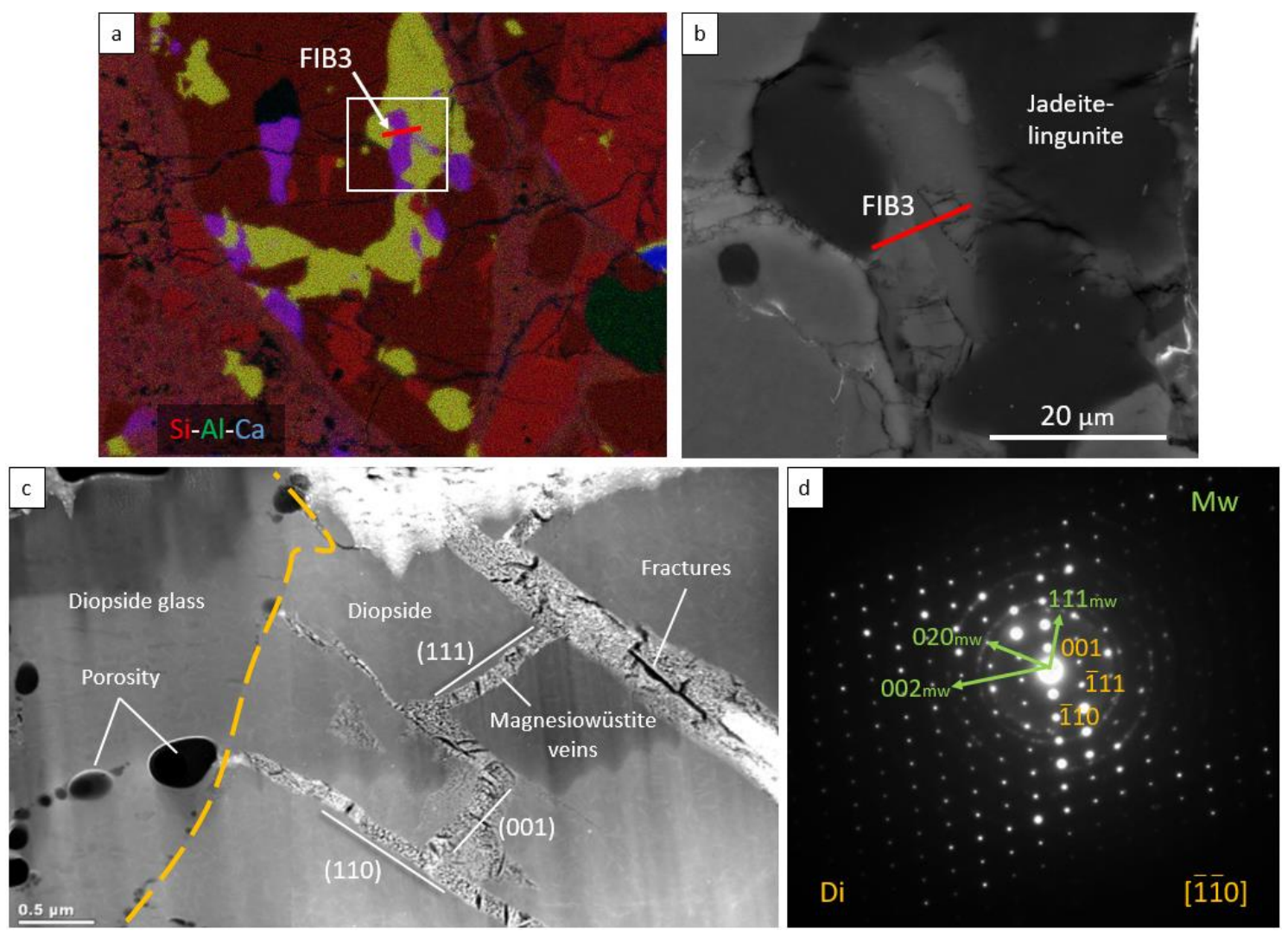

Fig. 6. SEM and TEM images of Ca-Mg-rich phase in the shock vein of Villalbeto. a) Si-Al-Ca RGB X-ray map of the entrained chondrule fragment in the vein (Si-Al-Ca). b) BSE image showing the position of the TEM foil extracted by FIB in red. c) HAADF STEM image of the amorphous Ca-rich silicate phase (diopside melt), crystalline diopside, magnesiowüstite veins with abundant fractures, and porosity. d) [1T0] zone axis diffraction pattern from diopside (Di) with an indexed ring pattern from the nanocrystalline magnesiowüstite $(\mathrm{Mw})$.

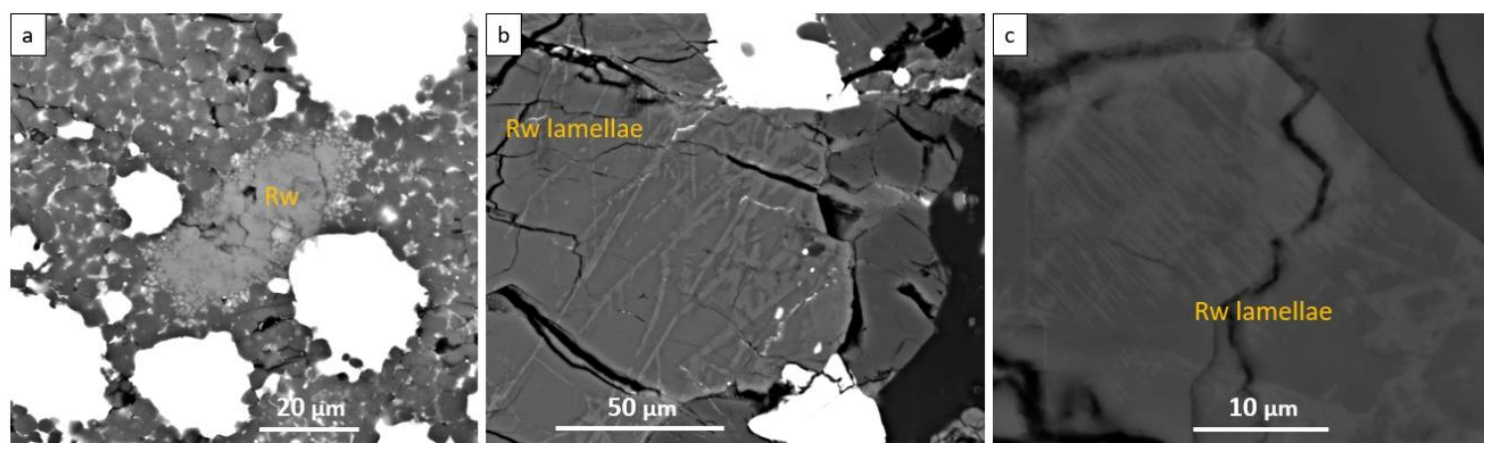

Fig. 7. Backscattered electron images of different ringwoodite textures in Villalbeto. a) Olivine fragment in the shock melt vein replaced by polycrystalline ringwoodite. b) Ringwoodite with thick lamellae $(50-60 \mu \mathrm{m})$ with higher iron content 
than the host grain. c) Olivine with thin $(\sim 1 \mu \mathrm{m})$ crystallographically-oriented lamellae of ringwoodite with higher Fe content near the vein.
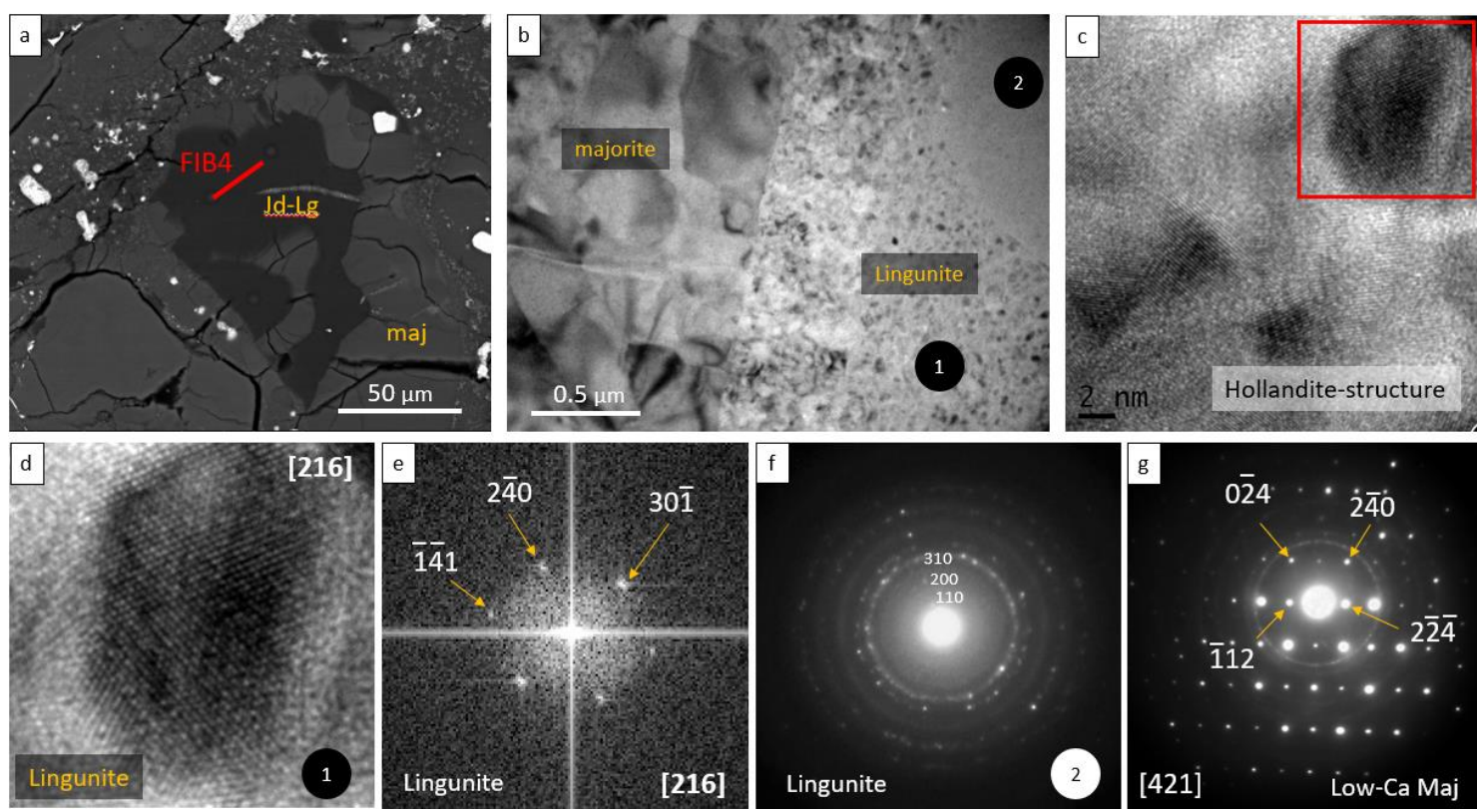

Fig. 8. a) SEM image of the jadeite-lingunite grain showing the location where the FIB section was extracted (FIB4). b) Bright-field TEM image of part of the FIB section in which majorite and lingunite are distinguished with a sharp boundary. Lingunite is present in two regions that are distinguished by different grain sizes that are separated by a distinct boundary. One region (marked as 1 in the figure) contains randomly oriented crystallites $<100 \mathrm{~nm}$ in size, whereas the second region (marked as 2 in the figure) consists of myriad nanocrystals of lingunite $<10 \mathrm{~nm}$ in size. c) Highresolution TEM image of the lingunite nanocrystallites from region (1) showing lattice fringes from multiple lingunite crystals in random orientations. d) Higher magnification image from the red square in figure (c). e) Corresponding FFT obtained from the crystallites shown in the red box in c), which can be indexed as the [216] zone axis of lingunite. f) Diffraction pattern of fine-grained region in (b) indicated as number 2, showing diffraction rings consistent with lingunite. g) [421] zone axis SAED pattern from a single crystal of low-Ca majorite. 

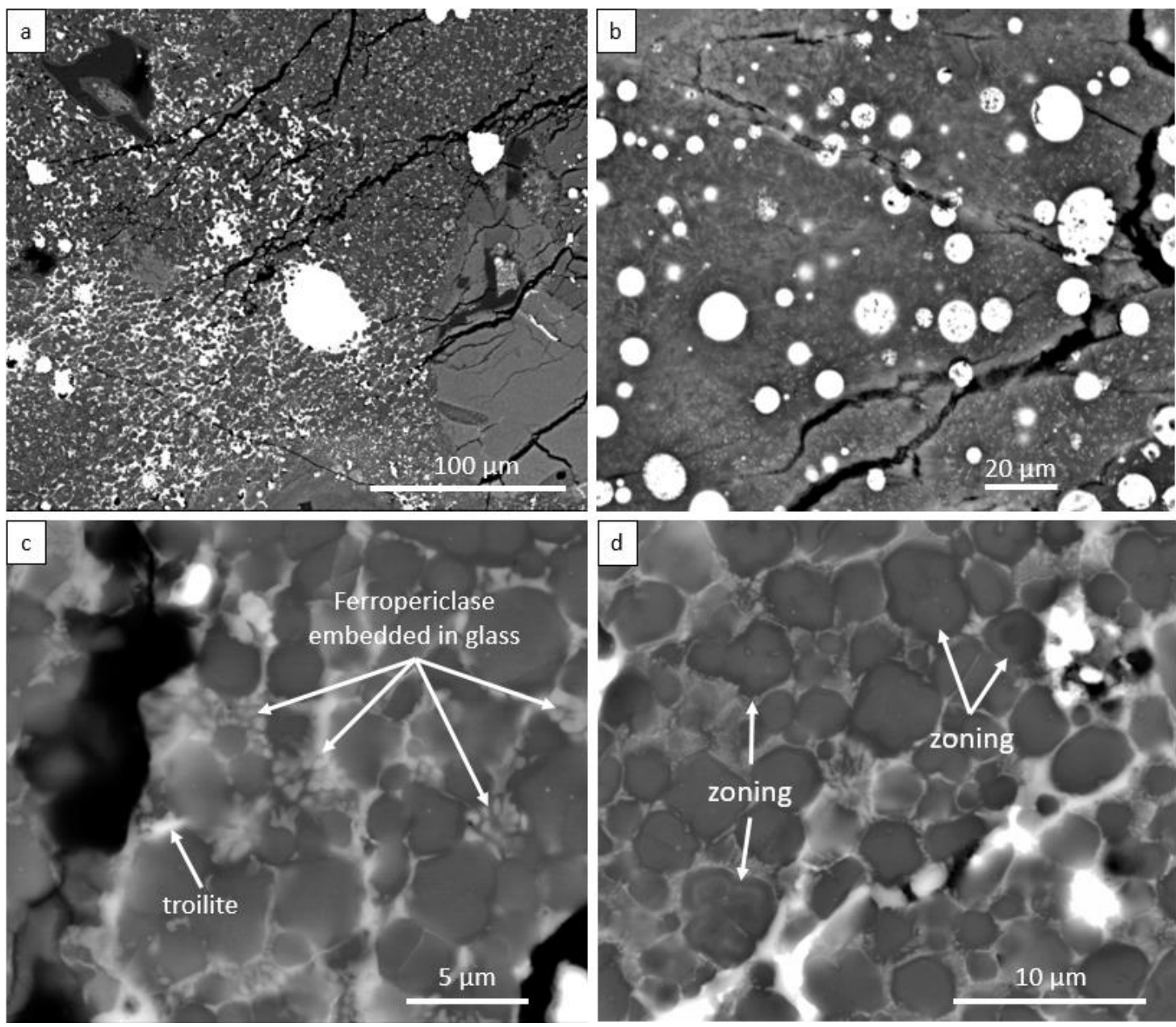

Fig. 9. Backscattered electron images showing the textures of the matrix in the main shock vein. A) Example of metal-troilite blebs with irregular or serrated edges in a central region of the vein. b) Example of metal-troilite spherules with rounded shapes in another part of the vein. c) Patches of interstitial ferropericlase grains between the majorite-pyrope grains are embedded in a glassy phase with lower BSE contrast. Troilite occurs along grain boundaries between the majorite-pyrope phase. d) Zoning in the majorite-pyrope solid-solution grains in a region of the matrix with a high abundance of majorite-pyrope grains with interstitial phases. Magnesium is higher at the rims $(0.5-1 \mu \mathrm{m})$ and most likely in all the cores as well $(\sim 2-4 \mu \mathrm{m})$, although only some grain cores are exposed at the surface of the sample (shown with arrows in the image). 


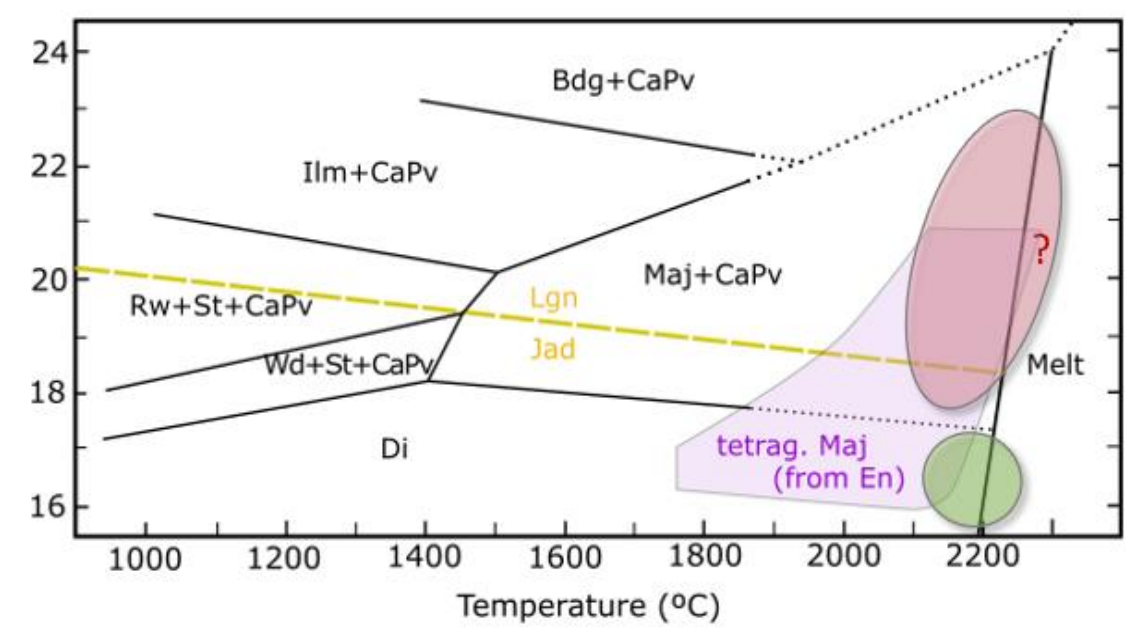

Fig. 10. Diopside phase equilibria diagram based on the experimental study of Akaogi et al. (2004), combined with the stability field of tetragonal majorite dissociated from enstatite $\left(\mathrm{MgSiO}_{3}\right)$ based on Gasparik (1990), and the jadeite-lingunite phase boundary from Akaogi (1989). The two stippled ovals represent the estimated peak shock conditions for FIB 3 (green) and FIBs 1, 2, and 4 (red). Legend: Di = diopside, $\mathrm{Wd}=$ wadsleyite, $\mathrm{St}=$ stishovite, $\mathrm{CaPv}=$ calcium perovskite, $\mathrm{Rw}=$ ringwoodite, $\mathrm{Ilm}=$ ilmenite, Maj = majorite, En = enstatite, Bdg = bridgmanite, $\mathrm{Jad}=$ jadeite, Lgn = lingunite. 


\begin{tabular}{|c|c|c|c|c|c|c|c|c|c|c|c|c|c|c|c|c|c|c|c|c|c|c|c|}
\hline Mineral & \multicolumn{2}{|c|}{$\begin{array}{l}\text { Olivine } \\
\text { (HR) }\end{array}$} & \multicolumn{2}{|c|}{$\begin{array}{l}\text { Ringwoodite } \\
\text { (HR) }\end{array}$} & \multicolumn{2}{|c|}{ Enstatite (HR) } & \multicolumn{2}{|c|}{$\begin{array}{l}\text { Ca-poor maj } \\
\text { (SMV) }\end{array}$} & \multicolumn{2}{|c|}{$\begin{array}{l}\text { Ca-rich maj } \\
\quad(\mathrm{SMV})\end{array}$} & \multicolumn{2}{|c|}{ Masklynite (HR) } & \multicolumn{2}{|c|}{$\begin{array}{l}\text { Jad-ling } \\
\text { (SMV) }\end{array}$} & \multicolumn{2}{|c|}{$\begin{array}{l}\text { Maj-pyrope } \\
\text { (SMV) }\end{array}$} & \multicolumn{2}{|c|}{$\begin{array}{l}\text { Maskelynite } \\
\text { (intergrowth) }\end{array}$} & \multicolumn{2}{|c|}{$\begin{array}{c}\text { Merrillite } \\
\text { (intergrowth) }\end{array}$} & \multicolumn{2}{|c|}{$\begin{array}{c}\text { Chromite } \\
\text { (intergrowth) }\end{array}$} & \multirow[t]{2}{*}{$\begin{array}{l}\text { Chromite } \\
\text { (mean L- } \\
\text { chondrite) }\end{array}$} \\
\hline $\mathbf{n}$ & \multicolumn{2}{|c|}{15} & \multicolumn{2}{|c|}{9} & \multicolumn{2}{|c|}{11} & \multicolumn{2}{|c|}{3} & \multicolumn{2}{|c|}{4} & \multicolumn{2}{|c|}{4} & \multicolumn{2}{|l|}{8} & \multicolumn{2}{|c|}{3} & \multicolumn{2}{|c|}{3} & \multicolumn{2}{|c|}{3} & \multicolumn{2}{|c|}{3} & \\
\hline \multicolumn{24}{|c|}{ Chemical composition (wt\%) } \\
\hline & av & $\sigma$ & av & $\sigma$ & av & $\sigma$ & av & $\sigma$ & av & $\sigma$ & av & $\sigma$ & av & $\sigma$ & av & $\Sigma$ & av & $\sigma$ & av & $\sigma$ & av & $\sigma$ & av \\
\hline $\mathrm{SiO}_{2}$ & 37.64 & 0.31 & 37.55 & 0.32 & 54.67 & 0.55 & 54.33 & 0.10 & 53.22 & 0.38 & 65.52 & 0.36 & 65.98 & 0.89 & 49.04 & 0.39 & 65.29 & 0.40 & 0.10 & 0.06 & 0.05 & 0.03 & \\
\hline $\mathrm{P}_{2} \mathrm{O}_{5}$ & 0.03 & 0.03 & 0.03 & 0.02 & 0.01 & 0.02 & 0.02 & 0.02 & 0.01 & 0.01 & 0.02 & 0.02 & 0.05 & 0.03 & 0.09 & 0.02 & 0.01 & 0.01 & 43.62 & 1.79 & 0.02 & 0.01 & \\
\hline $\mathrm{TiO}_{2}$ & 0.01 & 0.01 & 0.05 & 0.01 & 0.18 & 0.02 & 0.20 & 0.03 & 0.46 & 0.03 & 0.07 & 0.02 & 0.04 & 0.03 & 0.13 & 0.03 & 0.04 & 0.01 & 0.02 & 0.02 & 3.06 & 0.02 & 2.81 \\
\hline $\mathrm{Al}_{2} \mathrm{O}_{3}$ & 0.01 & 0.02 & 0.03 & 0.06 & 0.15 & 0.02 & 0.15 & 0.01 & 0.47 & 0.02 & 22.24 & 0.44 & 23.04 & 0.81 & 2.83 & 0.34 & 22.1 & 0.40 & 0.03 & 0.02 & 5.13 & 0.08 & 5.3 \\
\hline $\mathrm{Cr}_{2} \mathrm{O}_{3}$ & 0.01 & 0.02 & 0.01 & 0.02 & 0.10 & 0.03 & 0.09 & 0.02 & 0.88 & 0.12 & 0.00 & 0.00 & 0.01 & 0.02 & 1.54 & 0.82 & 0.25 & 0.08 & 0.40 & 0.07 & 56.29 & 0.29 & 56.1 \\
\hline FeO\# & 23.02 & 0.39 & 23.38 & 0.62 & 14.24 & 0.68 & 13.95 & 0.07 & 5.20 & 0.14 & 0.25 & 0.11 & 0.39 & 0.08 & 11.74 & 0.87 & 0.19 & 0.04 & 0.50 & 0.20 & 30.18 & 0.07 & 33 \\
\hline MnO & 0.47 & 0.02 & 0.36 & 0.10 & 0.51 & 0.02 & 0.51 & 0.04 & 0.26 & 0.04 & 0.02 & 0.03 & 0.22 & 0.24 & 0.47 & 0.05 & 0.00 & 0.00 & 0.01 & 0.01 & 0.53 & 0.05 & 0.74 \\
\hline $\mathrm{SO}_{3}$ & 0.01 & 0.01 & 0.01 & 0.01 & 0.01 & 0.01 & 0.02 & 0.02 & 0.01 & 0.01 & 0.01 & 0.01 & 0.00 & 0.1 & 0.06 & 0.04 & 0.01 & 0.01 & 0.02 & 0.02 & 0.00 & 0.00 & \\
\hline MgO & 38.08 & 0.39 & 37.73 & 0.44 & 28.70 & 0.01 & 28.83 & 0.07 & 16.50 & 0.17 & 0.01 & 0.01 & 0.09 & 0.17 & 28.14 & 1.59 & 0.01 & 0.01 & 2.41 & 2.09 & 2.97 & 0.06 & 1.99 \\
\hline $\mathrm{CaO}$ & 0.03 & 0.03 & 0.06 & 0.08 & 0.73 & 0.13 & 0.87 & 0.05 & 21.63 & 0.38 & 2.23 & 0.01 & 2.54 & 0.47 & 1.92 & 0.28 & 2.07 & 0.07 & 45.97 & 5.98 & 0.05 & 0.04 & \\
\hline $\mathrm{Na}_{2} \mathrm{O}$ & 0.04 & 0.04 & 0.05 & 0.05 & 0.05 & 0.06 & 0.06 & $0 . .07$ & 0.59 & 0.04 & 6.76 & 0.42 & 7.41 & 1.06 & 0.64 & 0.11 & 6.51 & 0.18 & 2.06 & 1.47 & 0.01 & 0.01 & \\
\hline $\mathrm{K}_{2} \mathrm{O}$ & 0.00 & 0.00 & 0.01 & 0.00 & 0.01 & 0.00 & 0.01 & 0.00 & 0.01 & 0.01 & 0.81 & 0.14 & 0.59 & 0.14 & 0.01 & 0.00 & 0.86 & 0.02 & 0.06 & 0.03 & 0.01 & 0.01 & \\
\hline Total & 99.35 & & 99.28 & & 99.36 & & 99.04 & & 99.22 & & 97.94 & & 100.37 & & 96.62 & & 97.33 & & 95.19 & & 98.31 & & \\
\hline \multicolumn{24}{|c|}{ Cation formulae } \\
\hline $\mathrm{Si}$ & \multicolumn{2}{|c|}{0.99} & \multicolumn{2}{|c|}{0.99} & 1.9 & & 1.9 & & 1.9 & & 2.5 & & 2.87 & & & & 2.9 & & 0.0 & & & & \\
\hline $\mathbf{P}$ & & & & & & & & & & & & & & & & & & & 18. & & & & \\
\hline $\mathrm{Ti}$ & 0. & & & & 0.0 & & 0.0 & & 0.0 & & $0 . C$ & & 0.00 & & & & 0.0 & & 0.0 & & & & \\
\hline
\end{tabular}




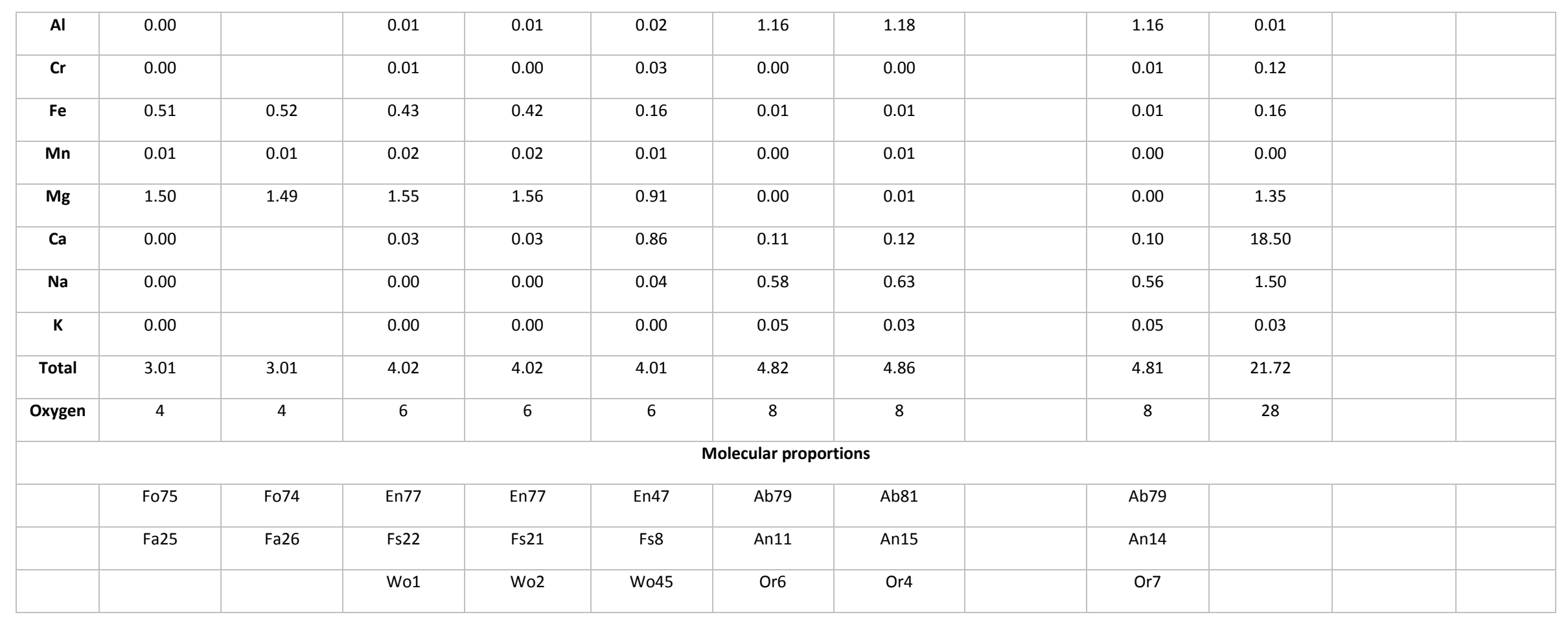

$\mathrm{HR}=$ host rock; SMV = shock melt vein; Maj= majorite; Jad-ling = jadeite-lingunite assemblage $; \mathrm{n}=$ numbers of analyses; av = average compositions of the minerals; $\sigma=$ standard deviation; \#all iron is assumed as ferrous. Mean L chondrite chromite values are from Bunch et al. (1967).

Table 1. Electron microprobe analyses of the minerals in the Villalbeto de la Peña host rock, their high-pressure polymorphs in the SMV, and in the chromite-maskelynite intergrowth. 